\title{
MARIUSZ MuSZYŃSKI
}

Uniwersytet Kardynała Stefana Wyszyńskiego

\section{ŚWIADOMOŚĆ UNORMOWANA. TOŻSAMOŚĆ NARODOWA I TOŻSAMOŚĆ EUROPEJSKA JAKO PRZEDMIOT PRAWA UE}

\section{WPROWADZENIE}

Znana nam międzynarodowa rzeczywistość została ukształtowana przez narody tworzące państwa. Proces ten jest analizowany w ramach szeroko rozumianych nauk społecznych. Jednak badania jakie dotychczas prowadzono zdominowała jedna treść. Była nią próba prognozy przyszłości państw narodowych tworzących społeczność międzynarodową. W wyprowadzonych wnioskach większość badaczy była pesymistami; zapowiadała upadek państwowości, erozję narodowych tożsamości i ustąpienie narodów przed supranarodową restrukturyzacją świata ${ }^{1}$.

Realia końca XX w. zaskoczyły naukowców. W społeczności międzynarodowej ujawniły się bowiem wręcz odwrotne tendencje. Rozpadły się państwa wielonarodowe tj. Jugosławia, Związek Sowiecki, pojawiły się siły odśrodkowe w Gruzji (Osetia, Abchazja), Belgii, czy siły dośrodkowe w podzielonym na dwa twory politycznopaństwowe narodzie niemieckim. Do dziś obserwujemy konflikty narodowe w Somalii, Palestynie, czy Czeczenii. Wydarzenia te pokazały

${ }^{1}$ Por. J.H. Rose, Nationality as a factor in Modern History, London 1916, s. 206. E. Hobsbawm, Nations and nationalism since 1780, Cambridge 1992, s. 188. 
nie tylko żywą siłę tożsamości narodowej, ale i podkreśliły, że jako desygnat jedności społeczeństw, nie odeszła ona w zapomnienie, a wyłącznie - jak każde zjawisko społeczne - ewoluowała.

W ciagu ostatnich 50 lat na świecie nie pojawiły się też na tyle atrakcyjne społecznie wielonarodowe twory, które byłyby w stanie całkowicie zastapić państwa narodowe. Udały się wprawdzie pomysły na szybkie przekształcenie wspólnot europejskich, konstrukcji od wielu lat akceptowanej przez Europejczyków, w unię politycznogospodarcza, ale już próba jej ewoluowania w federację z europejskim prezydentem, oficjalnym hymnem, flagą i innymi atrybutami państwowości potknęła się na dwóch referendach: francuskim (29 maja 2005) i holenderskim (1 czerwca 2005).

Niniejszy tekst dotyczyć będzie tematu tożsamości narodowej, a więc mentalnego spoiwa łączącego społeczeństwo każdego państwa w naród. Wprawdzie zasadniczo zjawisko tożsamości jest przedmiotem badań nauki socjologii, jednak takie przypisanie nie oznacza, że nie można na problem spojrzeć z perspektywy nauk prawnych. W szczególności z perspektywy prawa Unii Europejskiej. Celem istniejącej dziś UE jest przecież doprowadzenie do „coraz ściślejszych związków” między narodami państw członkowskich, a tożsamość narodów jest nie tylko obiektem oddziaływania polityczno-prawnego w procesie integracji. Od 1992 r. właśnie w tym obszarze mamy już do czynienia z jej normatywną instytucjonalizacją. Na dodatek dzieje się to w dwóch kontekstach. Traktat o Unii Europejskiej nie tylko bowiem przywołuje tożsamość narodową, ale i konstruuje instytucję tożsamości europejskiej. Prawo wspólnotowe definiuje też pewne aspekty tożsamości, tworząc przy tym szereg narzędzi służących ich ochronie.

Treścią niniejszych rozważań nie będzie kolejna próba konceptualizacji obu zjawisk. To stanowi bowiem zadanie socjologii i politologii. Tekst będzie natomiast omawiać obie formy tożsamości jako element unijnego procesu normatywnego. W ten sposób przybliży koncepcję przyjęta przez twórców traktatów. Pewnie nie odpowie jednoznacznie na pytanie wielokrotnie stawiane w publicznym dyskursie - czy członkostwo w UE faktycznie automatycznie prowadzi do stopienia się narodów w europejski „demos”? Pokaże jednak istotę i relacje obu tych 
instytucji, przede wszystkim ich kluczowy kontekst - katalog instrumentów pozwalających na utrzymanie narodowej zwartości państw członkowskich, jaki i chroniących konstrukcję utworzonej ponadnarodowej tożsamości „europejskiej”. Analiza prowadzona będzie przy użyciu instrumentarium prawniczego - poprzez omówienie treści norm.

\section{NARÓD I TOŻSAMOŚĆ NARODOWA W UE}

\section{Tożsamość narodowa jako instytucja prawa UE}

Pojęcie narodu nie jest pojęciem prawnym. Zasadniczo jest zdefiniowane w socjologii i jako takie przyjmowane na użytek nauk prawnych. Naród nie jest też instytucją, której badaniem zajmuje się nauka prawa międzynarodowego. Dla niej naród jest czasem adresatem norm prawnych i z tej perspektywy znajduje się w zakresie jej zainteresowania.

Jednak dla prawnika zajmującego się problematyką międzynarodową, szczególny powód dla zainteresowania się sprawami narodu tworzy Traktat o Unii Europejskiej. Wraz z momentem, kiedy proces integracji europejskiej przekroczył granice gospodarcze, jednym z jego elementów stał się problem narodowej tożsamości społeczności krajów tworzących UE. Przedmiotem regulacji lub przynajmniej punktem odniesienia norm prawnych na poziomie ponadnarodowym stały się bowiem: kultura, nauka, religia, obyczaje czy moralność. Nowego wymiaru nabrała sprawa języka narodowego, postrzeganego dotychczas w kontekście narzędzia biznesu. Pojawił się również polityczny dylemat, czy narody, które istniały dotychczas w ramach państw narodowych, odnajdą się w nowej rzeczywistości europejskiej określonej traktatowym zadaniem ,stworzenia coraz ściślejszej Unii” - nie Unii państw, lecz narodów.

Przed ośrodkami decyzyjnymi stanęło też pytanie, czy tożsamości narodowe spajające społeczności poszczególnych państw członkowskich stanowią atrybut jednoczącej się Europy, do którego trzeba nawiązywać, czy też może przeszkodę dla procesu integracji. 
Dodatkowo zaistniała potrzeba stworzenia mechanizmu równoważącego zagrożenia polityczne. Dotychczas narody żyjące w społeczeństwach wielonarodowych przejawiały wynikające ze świadomości narodowej tendencje do blokowania asymilacji. W sferze politycznej przejawiało się to wolą autonomii politycznej, włącznie z własna państwowością. Wiązało się to narodowa konkurencyjnością - o przedmioty materialne, dostęp do zasobów energii, status, wpływy, terytorium itp. Socjologia nazywa to zasobami żywotnymi dla istnienia naro$\mathrm{du}^{2}$. Do wzmacniania poczucia narodowych więzi służyło prawo wewnętrzne, jak i ideologie zwane nacjonalizmami. Stworzenie prawnych gwarancji dla narodowej tożsamości w ramach UE, miało wyeliminować lub przynajmniej ograniczyć stosowanie polityczne instrumentów jej obrony.

Początkowo w prawnej koncepcji tożsamości narodowej na poziomie UE zastosowanie znalazła pierwsza koncepcja ${ }^{3}$. Uznano, że w nowej wspólnocie europejskiej konieczne stało się nie tylko stworzenie wspólnej przestrzeni gospodarczej, eliminowanie granic celnych, wizowych, zapewnienie swobody osiedlania się, czy stworzenie perspektywy praw podstawowych, ale i zagwarantowanie zachowania narodowych tożsamości. W traktacie z Maastricht, który powołał do życia Unię Europejską, w art. F ust. 1 zapisano, że „Unia szanuje tożsamość narodową jej państw członkowskich, których systemy rządów oparte są na zasadach demokratycznych". Zapis ten z jednej strony definiuje tożsamość narodową państw członkowskich na potrzeby procesu integracji jako ich historię, kulturę i tradycję, a $\mathrm{z}$ drugiej generalne zobowiązanie jej ochrony. $\mathrm{Z}$ tą normą koresponduje ust. 4 wstępu traktatu, w którym czytamy, że jego twórcy pragną ,pogłębić solidarność między ich narodami w poszanowaniu ich historii, kultury i tradycji”.

2 Por. szerzej K. KWAŚNIEwsKi, Onacjonalizmie inaczej, «Sprawy Narodowościowe» 5.1 [8] (1996).

${ }^{3}$ Ze względu na tempo odejścia od niej i stosunkowo krótki upływ czasu do chwili zmiany koncepcji (5 lat) można podejrzewać, że była to świadome polityczne działanie, tzw. stopniowe zmiany. Por. C. Mik, Prawo wspólnotowe, Warszawa 1999, s. 466. 
W tej samej tonacji literalno-werbalnej utrzymał się też traktat z Amsterdamu, aczkolwiek dokonano w nim zmiany systemowej. Dawny art. F otrzymał numer 6, a przepis gwarantujący poszanowanie przez UE tożsamości narodowej państw został przesunięty - stał się jego ust. 3 . Natomiast w nowym ust. 1 zawarto wartości uznane za aksjologiczny fundament, na którym opiera się Unia Europejska. Bez zmian przetrwała również treść traktatowego wstępu.

Pozornie wygląda to na korektę normy. Skutki takiej zmiany są jednak znaczące. Tożsamość narodowa straciła w ten sposób rangę fundamentu UE na rzecz art. 6 ust. $1 \mathrm{TUE}^{4}$. Oczywiście poszanowanie tożsamości narodowej nie może być z powodu zmiany miejsca w treści normy jakościowo mniejsze. Tym bardziej, że gwarancja pozostała w tym samym art. 6 TUE. Nie zmieniła się też treść samego obowiązku jej poszanowania, definiowana przez szereg konkretnych nakazów i zakazów spoczywających na Unii i Wspólnotach Europejskich. Deprecjacji doznała jednak ranga narodowej tożsamości, która nie jest już aksjologicznym fundamentem samej UE.

Kolejny problem to treść tożsamości narodowej w prawie UE. Pojęcie to nie jest identyczne z klasycznym, pozaprawnym rozumieniem tej instytucji. Jak wspomniano wcześniej, w rozumieniu Traktatu o UE, tożsamość narodowa postrzegana jest jako historia, tradycja i kultura narodów Unii. W naukach pozaprawnych pojęcie tożsamości narodowej nie jest jednoznacznie zdefiniowane. Jednak doktryna socjologii jest zgodna, że najczęściej spotykanym skojarzeniem jest uznanie tożsamości narodowej za zbiorową świadomość, więź, czy poczucie jedności, która tkwi w naro$\mathrm{dzie}^{5}$. Jest więc ona niewatpliwie zespołem elementów, które - traktowane

${ }^{4}$ Inaczej C. Miк, op. cit., s. 466. Pisze on: Do innej konkluzji może nas jednak doprowadzić wykładnia funkcjonalna. Zgodnie $\mathrm{z}$ nią, w ust. 1 wyrażone są zasady, które chociaż przejęte z realiów państwowych, mają odnosić się zwłaszcza do konstruowania wspólnotowej (unijnej) rzeczywistości instytucjonalno-prawnej, a więc pewnej nadbudowy nad urządzeniami państwowymi. Tożsamość narodowa nie mieści się w kręgu zasad, które mogłyby służyć temu celowi, plasując się wyłącznie w płaszczyźnie państwowej. Stąd być może logiczniejsze jest oddzielenie jej od zasad z ust. 1 i ujęcie w osobnym paragrafie.

${ }^{5}$ Por. artykuły w periodyku «Sprawy Narodowościowe», w szczególności 5.1 [8] (1996). 
przez naród jako wspólne dla niego samego - stanowiąjego spoiwo. W ten sposób istnienie tożsamości i jej ochrona ma żywotne znaczenie dla istnienia i rozwoju narodu, a tym samym państw, w których one żyją. Dążenie do zachowania tożsamości jest więc dążeniem do autonomii, która przejawia się w wysiłkach czynionych na rzecz samozachowania.

Tożsamość narodowa może więc być definiowana przez sumę elementów, które konstytuują naród. W pewnym uproszczeniu można powiedzieć, że należą do nich: kultura materialna (literatura, sztuka, muzyka, folklor), język, który wprawdzie jest składnikiem kultury, lecz zasługuje na szczególną uwagę i wyróżnienie ${ }^{6}$, historia oraz kultura duchowa (obyczaje i moralność publiczna, religia, symbole, a nawet kultura prawna).

Porównując tę treść do instytucji zdefiniowanej w TUE dochodzimy do negatywnego wniosku - tożsamość narodowa w rozumieniu unijnego prawa pierwotnego jest pojęciem węższym niż pojęcie socjologiczne. Nie wynika to jedynie z aspektu definicyjnego - oceny art. 6 ust. 3 TUE w kontekście ust. 4 wstępu do traktatu. Potwierdza to także szereg norm określających treść pojęcia „szanuje”, a więc tworzących po stronie UE i Wspólnot konkretne obowiązki prawne w odniesieniu do tożsamości narodowej państw członkowskich.

\section{OBOWIĄZKI WSPÓLNOTY WOBEC TOŻSAMOŚCI NARODOWEJ PAŃSTW} CZLONKOWSKICH

Obowiązki te można sprowadzić do dwóch grup: traktatowe nakazy działania Wspólnoty na rzecz tożsamości narodowej państw członkowskich oraz traktatowe nakazy powstrzymania się przez Wspólnotę

${ }^{6}$ Wspólny język, słownictwo, nawyki gramatyczne i werbalne są istotnymi cechami zbiorowości narodowej. To przez komunikowanie się, zbiorowość nabywa wiedze o sobie i utrwala świadomość. Powstaje w ten sposób więź i solidarność między jednostkami. Język jest więc narzędziem do powstania i utrzymania samoświadomości. Język nie tworzy jednak sacrum. Często wykracza on poza granice terytorialne państw, jak i zdarzają się narody mówiące kilkoma językami - Szwajcarzy, Kanadyjczycy. Należy jednak pamiętać, że brak jednolitości językowej może grozić jedności narodowej. Por. E. SHILs, Naród, narodowość i nacjonalizm a społeczeństwo obywatelskie, «Sprawy Narodowościowe» 5.1 [8] (1996), 15-17. 
od działania o charakterze porządkowym, kiedy państwo naruszy reguły wspólnotowe uzasadniając to ochroną tożsamości narodowej ${ }^{7}$. W autonomiczny sposób chroniony jest język narodowy, który z racji swej roli w sferze gospodarczej (język urzędowy) i politycznej (język autentyczny) posiada prawne gwarancje spoza systemu norm odnoszących się do elementów tożsamości narodowej. Trzecią formułę ochrony tworzą zobowiązania polityczne Wspólnoty odnoszące się do religii.

\subsection{Traktatowe nakazy działania Wspólnoty}

a. wspieranie kultury narodowej

Podstawowe obowiązki wspólnotowe w zakresie poszanowania tożsamości narodowej państw członkowskich zawarte są w art. 151 TWE. Nakazuje on Wspólnocie aktywność w zakresie wspierania spraw kultury $^{8}$ na poziomie europejskim, z zachowaniem przez państwa prawa do samostanowienia w tym obszarze przedmiotowym ${ }^{9}$.

Zgodnie $\mathrm{z}$ treścią ust. 1 oraz ust. 5 tej normy $\mathrm{i}$ w związku $\mathrm{z}$ art. 3 lit. q TWE, jest to jednak wyłącznie zlecenie rozwijania życia kulturowego w państwach członkowskich ${ }^{10}$. Oznacza, że działania

${ }^{7} \mathrm{~W}$ polskiej doktrynie systematykę dzieląca obowiązki na negatywne i pozytywne przyjmuje C. Mik, op. cit., s. 468 i n.

${ }^{8}$ Prawowspólnotoweniedefiniujejednakpojęciakultury.Doktrynauznajezaniązarówno kulturę elementy tzw. kultury wyższej (literatura, muzyka, sztuka itp.) jak i kulturę masową.

${ }^{9}$ Wprawdzie Rada działa w obszarze kultury już od początku lat 80 . XX w. w drodze formuły mieszanej, jednak bezpośrednia kompetencja wspólnotowa została wprowadzona dopiero na drodze traktatu z Maastricht. Do tego czasu działania były oparte na ogólnych przepisach z zakresu wspólnego rynku i miały wymiar integracyjnopolityczny (art. 235 /obecnie art. 308 Traktatu ustanawiającego WE/. Od Maastricht mają konkretna podstawę. Podobnie I.E. SchwarTz, Subsidiarität und EG-Kompetenzen - Der neue Titel „Kultur” - Medienvielfahlt und Binnenmarkt, «AfP» (1993), s. 409.

${ }^{10}$ Już Rada Europejska w Edynburgu przypisała koncepcji komplementarnych działań wspólnotowych wyjaśniając, ze z zastrzeżeniem celów traktatowych, przy wyborze środków wspólnotowych, te maja pierwszeństwo, dzięki którym wspierana będzie współpraca między państwami, oraz te, które koordynują, uzupełniają, wspierają i dopełniają działania państw członkowskich. 
wspólnotowe nie mogą stanowić ani konkurencji, ani ujednolicenia, ani uzupełnienia polityki państw narodowych w zakresie kultury. Rola Wspólnoty sprowadza się do trzech elementów: zachęcania, wspierania i uzupełniania polityki krajowej. Działalność ta nie może ani określać wyniku polityki kulturowej, ani przyjmując formę wytycznych czy koordynacji - współokreślać jej ${ }^{11}$. Musi stanowić jedynie wsparcie. Dlatego wszystkie jej działania muszą raczej warunkować własna politykę kulturową państw ${ }^{12}$. Także wszelka aktywność Wspólnoty skutkująca obciążeniami finansowymi dla państw jest sprzeczna z ratio legis ust. 1 art. $151 \mathrm{TWE}^{13}$. Nawet jeśli państwa wykonują swe kompetencje w niewystarczającym zakresie, całościowa i własna polityka kulturowa jest Wspólnocie zabroniona.

Politycznym celem normy jest ustanowienie gwarancji dla różnic w polityce kulturalnej państw członkowskich ${ }^{14}$ jako wyrazu poszanowania tożsamości narodowej. W ten sposób kultura podlega przede wszystkim państwom, co art. 151 TWE uznaje poprzez umieszczone w nim przesłanek ,uzupełnianie” i wspieranie”. Jednak poprzez aktywność wspólnotowa, twórcy traktatu odrzucają całkowity partykularyzm państwowy. Każdy kraj musi poprzez swoje „obowiązki współdziałania"15 być pomocny Wspólnocie przy wykonywaniu jej zadań ${ }^{16}$.

Wspólnotowe zachęcanie do współpracy miedzy państwami odpowiada też zawartemu w preambule do traktatu życzeniu państw członkowskich, wzmacniania solidarności z poszanowaniem ich historii, kultury i tradycji. Stąd zadanie Wspólnoty to również stymulowanie

${ }^{11}$ Por. J. Hochbaum, Der Begriff der Kultur im Maastrichter und Amsterdamer Vertrag, «BayVBl» (1997), s. 681.

12 Por. J. Hochbaum, op. cit., s. 682.

13 Tak samo J. HochBaum. op. cit.

14 J. HochBaum, op. cit., s. 681.

15 Por. ETS 1987/242.

${ }^{16}$ Por. I. Berggreen-Merkel, Die rechtliche Aspekte der Kulturpolitik nach dem Maastrichter Vertrag, Wykład w Europa-Institut, Universität des Saarlandes, Saarbrucken1995, s. 16. Niepublikowany. Dostępny na www.europainstitut.de. 
współpracy dwu- i wielostronnej miedzy państwami członkowskimi, aczkolwiek pewne ramy wydaje się wprowadzać ust. 2 normy.

Działalność Wspólnoty ma więc charakter subsydiarny ${ }^{17}$. Wytyczne dla zakresu działań na poziomie wspólnotowym daje Protokół o stosowaniu zasad pomocniczości i proporcjonalności - z uwzględnieniem wniosków końcowych Rady Europejskiej z Birmingham oraz z Edynburga. Z obowiązku działania o charakterze pomocniczym nie da się jednak wywieść, że Wspólnota może być aktywna jedynie na wniosek państwa członkowskiego. Raczej uznaje się tu jej prawo do aktywności. Odmawia się jej natomiast prawa planowania działań w tym obszarze. Aktywność ma spełniać przesłanki solidarności i celowości, a sama Wspólnota zabezpieczyć odpowiednie środki budżetowe ${ }^{18}$. W efekcie o konieczności działań wspierających i uzupełniających decydują przy wspólnotowych akcjach zgodne oceny państw członkowskich. W świetle zasady solidarności możliwe jest też wsparcie pojedynczego państwa członkowskiego, o ile idzie o sprawę o znaczeniu europejskim ${ }^{19}$.

Zakres podjętego działania zależy jednak wyłącznie od woli Wspólnoty. Realizuje ona bowiem w ten sposób własne cele, w ramach prowadzonej przez siebie ,uzupełniającej” polityki kulturalnej, która powinna pozostawać jedynie w związku z polityką państw członkowskich. W przypadku, kiedy państwa członkowskie realizują swe kompetencje w obszarach kultury europejskiej w sposób niewystarczający, możliwe jest nawet samodzielne realizowanie polityki kulturalnej przez Wspólnotę ${ }^{20}$.

Współpraca między państwami UE kieruje się na zróżnicowane szeroko ujęte obszary aktywności. Są to wskazane w normie: pogłębianie wiedzy oraz upowszechnianie kultury i historii europejskich narodów; zachowanie i ochrona dziedzictwa kulturowego o znaczeniu europej-

${ }^{17} \mathrm{Na}$ podobieństwo konstrukcji $\mathrm{z}$ art. 126 ust. 1 i art. 129 ust. 1 TWE (zatrudnienie).

${ }^{18}$ Por. też J. Hochbaum, op. cit.

${ }^{19}$ G. Roess, Die neue Kulturkompetenz der EG, «DOeV» (1992), s. 949 i n.

${ }^{20}$ G. Roess, op. cit. 
skim; niehandlowa wymiana kulturalna; twórczość artystyczna i literacka, włącznie z sektorem audiowizualnym.

Celem działania w pierwszym obszarze nie jest jednak promocja narodowej tożsamości, jak się może wydawać z literalnego brzemienia normy. Tu współpraca państw ma skutkować przebudową partykularnego myślenia obywateli Unii warunkowanego historią własnego kraju w europejską świadomość. Wspieranie wspólnotowe dotyczy więc współpracy państw członkowskich na poziomie eksperckim w kwestiach metodyczno-dydaktycznych konceptów wyostrzających perspektywę europejską w zakresie literatury i programów informacyjnych. Uznaje się, że książki szkolne i naukowe w dziedzinie historii, nauki o państwie, polityce i społeczeństwie potrzebują europejskiego elementu. Chodzi tu również ułatwienie dostępu do informacji o historycznych wydarzeniach całej Europy, programach wymiany uczniów i dorosłych jak i europejsko inspirowanych muzeach.

W drugim obszarze, norma w pierwszym rzędzie odnosi się do dziedzictwa materialnego w formie pomników, dóbr kultury, itp. Może jednak też dotyczyć dziedzictwa niematerialnego - języków, dialektów, tradycji muzycznej czy tanecznej. Warunkiem aktywności Wspólnoty jest także europejskie, a nie partykularne znaczenie tych dóbr.

Z kolei niehandlowa wymiana kulturalna obejmuje wszystkie formy wymiany kulturowej miedzy państwami. Przesłanka „niehandlowa” wyklucza jednak projekty nastawione na zysk. Natomiast działalność wspierająca jest skierowana na obszar twórczości artystycznej i literackiej, włącznie z sektorem audiowizualnym, odnosi się do tych przejawów życia kulturalnego, włącznie z działalnością twórczą, które nie utraciły swych korzeniu narodowych i regionalnych. Charakter wspólnotowej aktywności polega na podejmowaniu ekonomicznych i prawnych działań stymulujących i protegujących. Ma to miejsce w różnych sferach, np. podatkach, prawie socjalnym. Twórczość artystyczna może być też animowana poprzez stypendia. Najważniejszym przejawem w tym obszarze jest wydawanie książek ${ }^{21}$. Obejmuje

${ }^{21}$ U. EverLING, Buchpreisbindung im deutsche Sprachraum und Europäisches Gemeinschaftsrecht, München 1997, s. 28. 
to również literaturę fachową. W treści normy jest też wyraźnie podkreślony sektor audiowizualny. Stąd obejmuje ona obszar filmowy, radio itp. Ponieważ jednak transgraniczna działalność nadawcza jest wg orzecznictwa ETS działalnością usługową (art. 49 TWE)22, działalność uzupełniająca Wspólnoty w tym obszarze jest dopuszczalna jedynie w formie sponsorowania scenariuszy, audycji, wykładów autorskich, zawodów muzycznych, festiwali filmowych i kanałów kultury w radiu i TV.

Brzmienie i systematyka normy pokazuje, że obszary w niej wskazane stanowią enumeratywne wyliczenie. Są jednak też zwolennicy jej interpretacji celowej, co pozwalałoby dopuszczać działalność WE w innych podobnych obszarach ${ }^{23}$.

Formy działania Wspólnoty odpowiadają komplementarnemu charakterowi celowi. Są to środki wspierające, o charakterze instrumentów prawnych formalnie nieokreślonych. Stanowią kategorię sui generis w katalogu niezamkniętym instrumentów. Jeśli musza przyjąć formę prawną - praktyka pokazuje, że stosuje się formę decyzji. Te instrumenty wykorzystuje się przede wszystkim do tworzenia programów wspierających. Katalog działania uzupełniają zalecenia. Zgodnie z art. 249 TWE, zalecają adresatom działanie, nie wiążąc ich. Przez sądy państw członkowskich powinny być jednak przestrzegane ${ }^{24}$. W związku z ograniczoną rolą Wspólnoty w obszarze kultury, art. 151 ust. 5 TWE zabrania stosowania środków o charakterze harmonizującym.

b. kultura jako (quasi) wspólnotowa polityka zewnętrzna

Jednym z elementów regulowanych przez Traktat ustanawiający WE jest też podział kompetencji miedzy państwa członkowskie a Wspólnotę w obszarze zewnętrznej polityki kulturowej, tzn. w re-

${ }^{22}$ Por. orzecznictwo ETS 1973/155 (1974) Sacchi. Por. też protokół nr 9 do traktatu amsterdamskiego.

${ }^{23}$ K. Bohr, H. Albert, Die Europäische Union - das Ende der eigenständigen Kulturpolitik der deutsche Bundesländer? «ZRP» (1993), s. 61.

${ }^{24}$ Por. ETS 1989 I-4407 Grimaldi. 
lacjach z państwami trzecimi ${ }^{25}$, jak i z organizacjami międzynarodowymi w obszarze kultury. Wśród tych ostatnich na pierwsze miejsce wysuwa się skonkretyzowana poprzez art. 303 Traktatu ustanawiającego WE, Rada Europy, postrzegana jako utożsamienie europejskiej polityki kultury.

Zgodnie z art. 151 ust. 3 TWE, do współpracy międzynarodowej w zakresie kultury powołane są jednak nie tylko państwa członkowskie, ale i Wspólnota. Mimo, że norma ta zawiera skromną treściowo formułe ,sprzyjają", to przykłady uprawnień WE w tym zakresie widać w układach stowarzyszeniowych i europejskich ${ }^{26}$. Natomiast doktryna spiera się w kwestii, czy Wspólnota dysponuje kompetencjami do zawierania własnych umów w tym zakresie. Niektórzy autorzy odmawiaja jej tego wskazując na brak odpowiedniej podstawy prawnej $\mathrm{w}$ art. 151 ust. 3 TWE, w porównaniu z innymi normami traktatowymi np. $\mathrm{z}$ art. 174 ust. 4 ak. $1 \mathrm{zd} .2$ TWE (środowisko naturalne) lub $\mathrm{z}$ art. 181 ust. 1 zd. 2 TWE (współpraca na rzecz rozwoju). Poważnym zarzutem przeciwko takiej kompetencji jest też brak charakteru regulującego instrumentów działania określonych $w$ art. 151 ust. $5 \mathrm{TWE}^{27}$.

Z kolei reprezentanci przeciwnego stanowiska wychodzą z założenia, ze wprawdzie nie ma jasnej normy kompetencyjnej, ale należałoby uznać takie kompetencje jako dorozumiany aneks aktualizujący kompetencje wewnętrzne $\mathrm{w}$ zakresie celów $\mathrm{z}$ ust. $2^{28}$. Z kolei trzecia grupa uważa, że umowy międzynarodowe w obszarze kultury Wspólnota może zawierać wyłącznie w formie umów mieszanych ${ }^{29}$, w związku

${ }^{25}$ Por. Lome III i Lome IV. Dz.Urz. WE 1986 L. 86/3 oraz Dz.Urz. WE 1993 L. 229/3.

${ }^{26}$ Lista takich porozumień znajduje się w dokumencie roboczym Komisji SEK (96) 686 z 23 kwietnia 1996 r. Załącznik 2 „Zewnętrzne stosunki kulturowe”.

${ }^{27}$ Por. Sт. Schmahl, Die Kulturkompetenz der Europäischen Gemeinschaft, BadenBaden 1996, «Nomos Universitätsschriften», tom 223 [Prawo], s. 204.

${ }^{28}$ G. Ress, J. Ukrow, [w:] E. Grabitz, M. Hilf, EU/EG-Kommentar, München 2002, Nota 29 do art. 151. Również: J. Sparr, [w:] J. Schwartze, UE Kommentar, Baden-Baden 2000, Nota 50 do art. 151. Odmawiają kompetencji Wspólnocie z powodu podziału kompetencji w obszarze kultury.

${ }^{29}$ Por. H. Blanke, [w:] E. Grabnitz, M. Hilf, EU/EG Kommentar, Nota 37 do art. 126. Por. także I. HochBaum, op. cit., s. 683. 
z istniejącymi kompetencjami zewnętrznymi państw członkowskich. Państwa członkowskie mogą natomiast same zawierać umowy kultural$\mathrm{ne}^{30}$. Są zobowiązane do uwzględniania Wspólnoty tylko w przypadku kiedy dotykają tematów zawartych już w umowach wspólnotowych ${ }^{31}$.

\section{c. zastrzeżenie kulturowe}

Szczególnym elementem normy jest klauzula z ust. 4. Nie tworzy ona nowych kompetencji dla Wspólnoty na rzecz państw członkowskich $^{32}$. ETS uznał też, że art. 151 ust. 4 Traktatu ustanawiającego WE nie uprawnia państw członkowskich do odmowy wprowadzania przepisów dyrektyw, czy wydawania norm ostrzejszych niż prawo wspólnotowe $^{33}$. Stanowi jednak specyficzne zastrzeżenie - nakazuje Wspólnocie uwzględnianie elementów kulturowych podczas wykonywania kompetencji z innych przepisów.

W ten sposób powstaje dla wszystkich polityk wspólnotowych nakaz uwzględniania interesów kulturowych państw członkowskich ${ }^{34}$ oraz obowiązek ochrony wspólnego europejskiego dziedzictwa kulturowego $^{35}$. W działaniach instytucji WE konieczne jest więc ważenie dóbr i stworzenie równowagi między interesem państw członkowskich, a innym - z reguły gospodarczym celem traktatowym, szczególnie wspólnotowymi wolnościami i zasadą wolnej konkurencji ${ }^{36}$.

${ }^{30}$ Por. I. Hochbaum, op. cit.

${ }^{31}$ Por. I. HochBaum, op. cit., s. 654.

${ }^{32}$ Por. M. Niedobitek, Die Kulturelle Dimensionen im Vertrag über Europäische Union, «EuR»1995, s. 362.

${ }^{33}$ Por. orzecznictwo: ETS C-11/95; ETS C-85/94.

${ }^{34} \mathrm{~W}$ sprawie tożsamości aspektów kulturowych z kulturowymi interesami państw członkowskich porównaj: I.E. SchWARTz, op. cit, s. 426; I. HochBAum, op. cit., s. 684; U. Everling, Buchpreisbindung, cit., s. 34.

${ }^{35}$ G. RoEss, op. cit., s. 947.

${ }^{36}$ Porównaj: Ersten Bericht über die Berücksichtigung der kulturellen Aspekte in der Tätigkeit der Europäischen Gemeinschaft (KOM [96] 160. Por. tez: M. NiEdobiteK, Die Kulturelle Dimensionen, cit., s. 374.; J. HochBaum, op. cit., s. 684; U. EverLing, 
Czy interesy państw są jednak najważniejsze? Przecież postrzegane są jako najważniejszy warunek jedności kulturowej w tej europejskiej różnorodności ${ }^{37}$. Przewaga interesu państwowego nie ma w tym przypadku charakteru bezwzględnego. O ile pojawia się problem konkurencji z inna normą traktatowa, pierwszeństwo aspektu kulturowego zależy od tego, jak jest rozłożony ciężar każdorazowych działań z uwagi na cel, treść i skutek ${ }^{38}$.

\subsection{Traktatowe nakazy zaniechania działania wspólnotowego}

\section{a. wyjątek od zakazu ograniczeń}

Traktatowe nakazy zaniechania działania przez organy wspólnotowe dotyczą dwóch elementów tradycyjnej (socjologicznie rozumianej) tożsamości narodowej: kultura i moralność publiczna. Przy czym należy jednak podkreślić, że drugi z nich funkcjonuje de facto, chociaż nie jest elementem traktatowej definicji zawartej w ust. 4 wstępu do Traktatu o UE. Postrzega on tożsamość narodową jako historię, kulturę i tradycje. Problem moralności publicznej można więc rozwiązać dwojako. Po pierwsze, przy odrobinie dobrej woli, można spróbować doszukać się miejsca dla moralności publicznej w granicach tradycji narodowej. W przeciwnym razie - i skoro moralność publiczna jest elementem definicji pozatraktatowej -można traktatowi postawić zarzut braku spójności w tym kontekście. Oba instrumenty zawarte są w art. $30 \mathrm{TWE}^{39}$.

Buchpreisbindung, cit., s. 35.

${ }^{37}$ Przewiduje to M. NiEDoBiteK, Kultur und Europäisches Gemeinschaftsrecht, Berlin 1992, s. 374

${ }^{38}$ ETS $1991-$ I, 2867.

39 „Postanowienia artykułów 28 i 29 nie stanowią przeszkody w stosowaniu zakazów lub ograniczeń przywozowych, wywozowych lub tranzytowych, uzasadnionych względami moralności publicznej, porządku publicznego, bezpieczeństwa publicznego, ochrony zdrowia i życia ludzi i zwierząt lub ochrony roślin, ochrony narodowych dóbr kultury o wartości artystycznej, historycznej lub archeologicznej, bądź ochrony własności przemysłowej i handlowej. Zakazy te i ograniczenia nie powinny jednak 
Zgodnie $\mathrm{z}$ traktatem, jeśli jakiś określony środek spełnia warunki dla zaistnienia zakazu ilościowego czy działania o podobnym skutku, podlega pod stan prawny z art. $28 \mathrm{TWE}^{40}$ oraz art. $29^{41}$ TWE i jest zakazany. Ponieważ jednak nie wszystkie regulacje z zakresu wspólnego rynku są poddane harmonizacji, prawo wspólnotowe pozwala równocześnie państwom członkowskim na ochronę niektórych dóbr prawnych i odstępowanie od wspólnotowych zakazów. Art. 30 TWE zawiera właśnie cały szereg takich podstaw.

Wśród nich jest możliwość zastosowania krajowych środków ochrony narodowych dóbr kultury o wartości artystycznej, historycznej lub archeologicznej. Jednak art. 30 TWE nie pozwala chronić wszelkich dóbr kultury, a tylko takie, które mają większe lub specyficzne znaczenie z punktu widzenia historycznego lub artystycznego. Państwa korzystają przy tym z dużego marginesu swobody.

Zakres płaszczyzny ochrony, którą chcą państwa zagwarantować, pozostaje $\mathrm{w}$ zakresie ich decyzji. Istotą zastosowania przesłanki jest ochrona interesów krajowych, którym przypisane są określone wartości artystyczne, historyczne lub archeologiczne - ważne dla narodowej tożsamości. Musi więc chodzić o konkretne dobro kultury, a więc jasno o jakiś przedmiot. Jednak art. 30 TWE nie może mieć zastosowania abstrakcyjnego, a jedynie pod warunkiem zaistnienia konkretnego niebezpieczeństwa dla dobra chronionego. Oczywiście spełnienia takiej przesłanki państwo nie musi udowadniać naukowo, jednak powinien istnieć realny czynnik możliwy do wskazania jako zagrożenie. Przyjęty środek musi być też odpowiedni do celu (proporcjonalny). Nie jest taki, jeśli dane państwo członkowskie nie podejmie

stanowić środka arbitralnej dyskryminacji ani ukrytych ograniczeń w handlu między Państwami Członkowskimi”.

${ }^{40}$ Art. 28 TWE: Ograniczenia ilościowe w przywozie oraz wszelkie środki o skutku równoważnym są zakazane między Państwami Członkowskimi.

${ }^{41}$ Art. 29 TWE: Ograniczenia ilościowe w wywozie oraz wszelkie środki o skutku równoważnym są zakazane między Państwami Członkowskimi. 
go również wobec takich samych towarów produkowanych na swoim terytorium $^{42}$.

Generalizując, środki są nieodpowiednie, jeśli nie są podejmowane w tym samym zakresie wobec podobnych stanów faktycznych. Uchylenie się od obowiązków traktatowych jest wykluczone, jeśli prowadzi do samowolnej dyskryminacji lub stanowi ukryte ograniczenie, nie jest odpowiednie dla celu chronionego lub dysproporcjonalne ${ }^{43}$.

Prócz art. 30 TWE ochronę kultury i respekt dla obyczajów narodowych i regionalnych zapewnia się metodą orzeczniczą ${ }^{44}$.

Wyjątek od zakazu ograniczeń odnosi się także do moralności publicznej. Wybór tej formuły wynika z faktu, że sama moralność nie jest przedmiotem regulacji prawa wspólnotowego. Dlatego jej ochrona prawna pojawia się jedynie w art. 30 Traktatu ustanawiającego WE w aspekcie negatywnym ${ }^{45}$. Dzięki niej państwa członkowskie mogą czynić podobne przeszkody w swobodnym przepływie towarów, jak w przypadku dóbr kultury.

Ochrona moralności publicznej jest pojemną podstawą działania władz krajowych. Mogą one samodzielnie określać wymogi moralności, korzystając z własnej (tradycyjnej) skali wartości i w formie, jaką wybiorą. Zakaz importu towarów z innych państw członkowskich musi jednak korespondować z zakazem produkcji lub komercjalizacji tych samych towarów w danym państwie.

b. wyjatki od zakazu pomocy publicznej

Druga podstawę prawna dla wspólnotowych obowiązków powstrzymania się od działania stanowi art. 87 ust. 3 TWE dotyczący wyjąt-

${ }^{42}$ ETS 1985/121.

${ }^{43}$ C. Мiк, op. cit.

${ }^{44}$ C. Мाк, op. cit. s. 468. Przywołuje wyroki ETS C-145/88; ETS C 1989, I-3851, ETS C 332/89 i inne.

${ }^{45}$ Treść jego brzmi: „Postanowienia art. 28 i 29 nie stanowią przeszkody w stosowaniu zakazów lub ograniczeń przywozowych, wywozowych lub tranzytowych uzasadnionych względami moralności publicznej...”. 
ków od zakazu pomocy publicznej. W interesującym nas kontekście tożsamości narodowej, jego zakres przedmiotowy odnosi się również do ochrony kultury narodowej. W ten sposób korzysta ona już z ochrony trzeciej traktatowej podstawy prawnej.

Zgodnie z prawem wspólnotowym, pomoc publiczna zarówno dla całych gałęzi przemysłu, jak i pojedynczych przedsiębiorstw, jest w UE zakazana. Podkreśla to wyraźnie art. 87 ust. $1 \mathrm{TWE}^{46}$. Jednak już kolejne dwa ustępy tej normy pokazują wyjątki od zakazu.

Przepisem interesującym dla niniejszych rozważań jest ust. 3 do art. 87. Formułuje on przesłanki, których spełnienie - oraz zgoda Komisji - oznaczają możliwość odstępstwa od generalnego zakazu. Norma umożliwiająca pomoc publiczną przeznaczoną na wspieranie kultury i zachowanie dziedzictwa kulturowego znajduje się pod literą d.

Przepis jest związany treściowo $\mathrm{z}$ art. 151 TWE, który określa zadania Wspólnoty w obszarze kultury ${ }^{47}$. Został wprowadzony w traktacie z Maastricht. Wcześniej Komisja mogła stosować do pomocy w sferze kultury tzw. pozytywne wstrzymanie się na podstawie norm $\mathrm{z}$ lit. c lub lit. b (norma $\mathrm{w}$ starym ujęciu), o ile nie miała miejsca dyskryminacja obywateli innych państw członkowskich ${ }^{48}$. Istotą obecnej normy jest upoważnienie dla Komisji do uznania pomocy państwowej za zgodną ze wspólnym rynkiem, jeżeli jej celem jest wspieranie kultury i ochrony dziedzictwa kulturowego. Zgodnie $\mathrm{z}$ traktatową granica, podjęta pomoc nie może zmieniać warunków wymiany handlowej i konkurencji we Wspólnocie w zakresie sprzecznym ze wspólnym interesem.

${ }^{46}$ Obszar Wspólnoty stanowi wolny rynek, którego głównym filarem jest zasada swobodnej konkurencji. Każde wsparcie finansowe ze strony państwa traktuje się jako jej zaburzenie.

${ }^{47}$ Por. 28. Raport Komisji dotyczący polityki konkurencji 1998, 1999. 275. ETS C-32/98.

${ }^{48}$ Por. 9 Raport Komisji o polityce konkurencji 1979, 1980. 239. 


\subsection{Ochrona języka}

Położenie prawne języka narodowego czy regionalnego państw członkowskich różni się w pewnym stopniu od niektórych innych elementów składających się na kulturę narodową. Jest to rezultatem faktu, że w realiach Wspólnoty Europejskiej język jest nie tylko obiekt dziedzictwa kulturowego. Spełnia on również dwie dodatkowe ważne role: jest instrumentem działalności gospodarczej, a szczególnie środkiem urzeczywistniania prawa wspólnotowego, tj. wyrażania jego materii w formach prawnych oraz obwieszczania go adresatom (język urzędowy). Jako język traktatowy jest także instrumentem polityki (język autentyczny). W zasadzie obie dodatkowe role gwarantują mu przetrwanie na użytek narodowej tożsamości ${ }^{49}$.

Pierwsza z ról przypisanych językowi to funkcja urzeczywistniania prawa. Na poziomie traktatowym reguluje to art. 290 TWE. Stanowi, że system językowy instytucji Wspólnoty określa Rada. Stanowi ona jednomyślnie, co podkreśla tu quasi-międzyrządowych charakter sprawy. Rozstrzygnięcie nie narusza to postanowień Statutu Trybunału Sprawiedliwości. ETS podlega wyłączeniu, bo zgodnie z art. 64 TWE sprawa jest uregulowana $\mathrm{w}$ jego statucie przyjętym przez państwa członkowskie ${ }^{50}$. Art. 290 TWE i przyjęte na jego podstawie akty prawne stosuje się odpowiednio do Wspólnej Polityki Zagranicznej i Bezpieczeństwa ${ }^{51}$ oraz III filara.

${ }^{49}$ Nakaz ograniczania działalności gospodarczej ze względu na ochronę języka może zostać jednak ograniczone wskutek przyjęcia harmonizujących norm wspólnotowych. W rezultacie np. w sferze etykietowania towarów, która podlega dyrektywie Rady nr 79/112 z 18.12.1978 r. państwo członkowskie nie może żądać, aby napisy na etykiecie były jedynie w określonym języku albo w języku dominującym w danym regionie, choćby było dopuszczalne równoległe używanie innego języka, ponieważ dyrektywa pozwala tylko na wymóg, aby etykieta była w języku łatwo zrozumiałym dla nabywcy. Do pogodzenia z nią są zatem tylko takie normy krajowe, które stanowią, iż języki nabywców mogą być używane alternatywnie.

${ }^{50}$ Protokół dotyczący Statutu Trybunału Wspólnot Europejskich załączony do Traktatu z Nicei.

${ }^{51}$ Deklaracja nr 29 do traktatu z Maastricht. 
Treściowych wskazówek art. 290 TWE nie zawiera. Państwa członkowskie mogą więc się tu na swój sposób dowolnie porozumieć w ramach jednomyślności. Granice określają jedynie inne przepisy traktatowe lub ogólne zasady prawa wspólnotowego. W ramach Traktatu ustanawiającego WE jest to zakaz dyskryminacji. Z nim wiąże się art. 22 Karty Praw Podstawowych, która chroni różnorodność języków. Nie bez znaczenia jest też art. 6 ust. 3 Traktatu o UE, który zobowiązuje UE do poszanowania tożsamości narodowej państw członkowskich; do tego należy oficjalny język państwowy.

Wspólnota inaczej niż inne organizacje międzynarodowe może wydawać akty prawne wiążące bezpośrednio obywateli państw. Dlatego muszą one spełniać zasady państwa prawa-być jednoznaczne, konkretne i zapewniać bezpieczeństwo prawne. Mogą być skierowane do obywatela tylko wtedy, jeśli może on zapoznać się z ich treścią w swym języku. W powiązaniu do zasad przejrzystości i bliskości do obywatela (art. 2 Traktatu o UE i art. 255 Traktatu ustanawiającego WE), pozwala się wyprowadzić niepisana ogólna zasada prawa wspólnotowego, że każdy obywatel powinien mieć prawo dostępu do dotyczących go przepisów w jego języku ${ }^{52}$. Choć z organizacyjnych względów mogą być wyjątki od tej zasady ${ }^{53}$.

${ }^{52}$ R. Schweitz, [w:] E. Grabnitz, M. Hilf, EU/EG Kommentar, Nota 11 do art. 290TWE.

${ }^{53}$ Chodzi nie tylko o ETS. Dla Komitetu Regionów i Komitetu EkonomicznoSpołecznego oraz innych organów, zasada ta także nie obowiązuje. Ich sprawy języka mogą być uregulowane przy uwzględnieniu innych norm traktatowych i ogólnych zasad prawa - w drodze regulaminów lub aktów prawa wtórnego. Tak np. Europejski Bank Centralny uregulował sobie tę sprawę samodzielnie (Art. 17 Statutu EBZ, Dz.Urz. WE 1999 L. 125/34), korzystając z autonomii, aczkolwiek zgodnie z rozporządzeniem nr 1/58. Natomiast urząd harmonizacyjny ds. rynku wewnętrznego, przyjął ograniczony reżim językowy (niemiecki, angielski, francuski, włoski, hiszpański - Art. 115 i następne Rozporządzenia Rady WE40/94 z 20.12.1993 r. Dz.Urz. WE 1994,L11/1). Choć ta praktyka jest sporna - czy jest uzasadnienie akurat dla takich ograniczeń, czy może jest to naruszenie zasad prawa wspólnotowego. Była skarga w tej sprawie, ale została oddalona ze względów proceduralnych (ETS - T-107/94; C -270/95 P). ETS pozwolił jednak wyraźnie na takie ograniczenie (ETS T-120/99; ETS 2001, II-2235. Krytycznie w tej kwestii: J. GundEL, Zur Sprachregelung bei den EG-Agenturen-Abschied auf Raten von der Regel der „Allsprachigkeit” der Gemeinschaft im Verkehr mit dem Burger, «EuR» (2001), s. 776). 
Na podstawie art. 290 TWE Rada wydała rozporządzenie nr $1^{54}$, które jest każdym przystapieniem nowego państwa nowelizowane. Zwrot traktatowy „system językowy” jest w rozporządzeniu skonkretyzowany przez pojęcia języka urzędowego i języka roboczego. Obowiązuje ono zgodnie z zakresem normy traktatowej odpowiednio dla instytucji. Zasada uznania za język urzędowy - każdy język urzędowy w państwie członkowskim, za wyjątkiem irlandzkiego i luksemburskiego. Języki regionalne i mniejszości nie mają tego statusu ${ }^{55}$.

Rozporządzenie określa zasady stosowania języka ${ }^{56}$. Naruszenie reżimu językowego może stanowić podstawę dla roszczeń odszkodowawczych w trybie 288 ust. Traktatu ustanawiającego WE.

Druga rola języka narodowego tworząca jednocześnie gwarancje w obszarze tożsamości to jego funkcja jako języka autentycznego. Gwarantuje ona równoprawną ochronęjęzyków państw członkowskich przez uznanie ich jednakowej autentyczności w odniesieniu do tekstów traktatowych i prawa wtórnego.

Sprawę reguluje art. 53 TUE oraz art. 314 TWE. Obie normy maja identyczne znaczenie. Art. 53 reguluje kwestie języków autentycznych w Traktacie o UE. Z kolei art. 314 Traktatu ustanawiającego WE odpowiada art. 53 Traktatu o UE i reguluje sprawy własnych języków autentycznych ${ }^{57}$.

Rola autentycznego języka traktatu wiąże się z trudnościami interpretacyjnymi ${ }^{58}$. Każdy z traktatów jest sporządzony w jednym orygina-

${ }^{54}$ Dz.Urz. WE 1958, nr 17/385 ze zmianami.

${ }^{55}$ PE Bericht im Namen des Petitionsausschusses über Sprachensituationen in der Europäischen Gemeinschaft und die Stellung des Katalanischen vom 27. Juni 1990. Dokument A3-169/90, s. 13.

${ }^{56}$ Należy tu odróżnić kwestie języków roboczych, wybieranych w ramach autonomii instytucji.

${ }^{57}$ Dodany w Amsterdamie do obydwóch norm ust. 2 (i odpowiednio rozszerzany na mocy traktatów akcesyjnych) odzwierciedla zasadę, że także języki państw nie będących członkami założycielami Wspólnoty, mają tę sama rangę - są językami autentycznymi.

${ }^{58}$ P. Braselmann, Übernationales Recht und Mehrsprachigkeit, «EuR» (1992); M. HILF, Die Auslegung mehrsprachiger Verträge. Eine Untersuchung zum 
le we wszystkich językach. Oryginał jest złożony do depozytu rządowi włoskiemu, który przekazuje każdemu państwu - stronie uwierzytelniony odpis. Tekst autentyczny oznacza, że wyniki interpretacji muszą być identyczne w swych skutkach. W przypadku wątpliwości interpretacyjnych przy wykładni TWE decydują zasady interpretacyjne wspólnotowe a nie ogólne zasady interpretacji traktatów ${ }^{59}$. ETS rozwinął tu zasady wykładni ${ }^{60}$. Dają się one również zastosować do TUE ${ }^{61}$.

Adresatem wykładni są nie tylko państwa członkowskie jako podmioty prawa międzynarodowego, ale wszystkie podmioty stosujące to prawo. Na scenie europejskiej są więc to instytucje i organy. Na poziomie państwowym wszystkie organy władzy, sądy i inne instytucje krajowe. Jeśli natrafią one na problemy interpretacyjne, powinny uwzględniać tekst w innych językach o ile norma nie podlega interpretacji ETS. W przeciwnym razie są zobowiązane postawić pytanie do ETS.

Völkerrecht und zum Staatsrecht der Bundesrepublik Deutschland, Heidelberg 1973; K. AmBruester, Rechtliche Folgen von Übersetzungsfehler und Unrichkeiten in EGDokumenten, «EuZW» (1990), s. 46.

${ }^{59}$ J. Schwartze, Das allgemeine Völkerrecht in den innergemeinschaftlichen Rechtsbeziehungen, «EuR» (1983), s.1. Por. też H. Doelle, Zur Problematik mehrsprachiger Gesetzes- und Vertragstekste, «RabelZ» 26 (1961), s. 27.

${ }^{60}$ ETS 283/81 ETS C-177/95, ETS 300/86. Przy interpretacji konieczne jest porównanie ujęć językowych ze względu na ich równa rangę, jednak żadnej z nich nie przypisuje się pierwszeństwa. Różnice musza być łagodzone w ten sposób, by mimo różnic możliwe było ich jednolite zinterpretowanie W tym celu patrzy się na przepisy w kontekście systemowym oraz zgodnie z ogólna budową i celem regulacji. Przy tym uwzględnia się, że prawo UE posiada własna terminologię, która nie koniecznie musi być zgodna z powszechnym prawem międzynarodowym.

${ }^{61}$ Nie wolno jednak zapominać, że w przypadku Traktatu o UE, jego art. 46 ogranicza kompetencje ETS, także w zakresie interpretacji. W stosunku do norm niepodlegających kompetencji ETS, stosuje się zasady interpretacji powszechnego prawa międzynarodowego, gdzie uwzględnia się art. 33 konwencji wiedeńskiej o prawie traktatów. Prowadzi to - przy uwzględnieniu że chodzi o jednolita wolę państw i ten sam traktat - do podobnych wyników jak zasady interpretacji przyjęte przez ETS. 
Nie można jednak nie zauważyć, że w prawie wspólnotowym pojawia się dodatkowe wsparcie różnorodności językowej. Chodzi tu o art. 149 TWE dotyczący edukacji. Nakłada on na Wspólnotę obowiązek przyczyniania się do podnoszenia poziomu oświaty, przy poszanowaniu m.in. właśnie różnorodności językowej. Rozwój europejskiego wymiaru edukacji ma odbywać się w szczególności przez nauczanie i upowszechnianie języków państw członkowskich ${ }^{62}$.

\subsection{Gwarancja polityczna dla religii}

Formuła ochrony politycznej odnosi się właściwie do jednego obszaru - religii. Określenie przez UE charakteru relacji z kościołami ma stosunkowo niedługa historię. Wiąże się z ustanowieniem unii politycznej w 1992 r. przez traktat z Maastricht. Do tego czasu, integracja gospodarcza Europy nie dotykała w ogóle problemu religii i kościołów, aczkolwiek Trybunał Sprawiedliwości kilkakrotnie zajmował się sprawami z zakresu prawnych stosunków państwo-kościób ${ }^{63}$.

Przyjęta konstrukcja jest rezultatem pozostawania religii poza zakresem kompetencji Wspólnoty, jak i prawem wspólnotowym. Zasadniczo swój stosunek do religii państwa określają w umowach międzynarodowych (konkordat) lub aktach krajowych różnej rangi dotyczących stosunku państwa do kościołów, albo całkowicie przemilczają.

Religia może jednak znaleźć się w zakresie działania Wspólnoty, gdy w jakiś sposób będzie wiązała się z działalnością gospodarczą w rozumieniu art. 2 TWE.

W obecnym stanie prawnym, kluczowym dokumentem jest przyjęta w Amsterdamie deklaracja nr 11 do traktatu amsterdamskiego w sprawie statusu Kościołów i organizacji niewyznaniowych.

${ }^{62} \mathrm{Z}$ zadaniem tym koresponduje też decyzja Rady z 21.11.1996 r. w sprawie przyjęcia programu wieloletniego promowania różnorodności językowej Wspólnoty w społeczeństwie informacyjnymi.

${ }^{63}$ Por. szerzej: G. RoBBerTs, $W$ sprawie artykulu kościelnego w Układzie Europejskim „Maastricht II', [w:] Europa i Kościót, pod red. H. Jurosa, Warszawa 1997. 
Potwierdza ona pewną linię postępowania Wspólnot. Zgodnie z jej treścią, UE szanuje kościoły i stowarzyszenia lub wspólnoty religijne w Państwach Członkowskich i nie narusza statusu, z którego korzystaja, na mocy prawa krajowego.

Uderzający jest ogólny charakter tekstu klauzuli. Tłumaczone jest to tym, ze tylko taka oszczędność zapewniła jednomyślna akceptację deklaracji przez wszystkich sygnatariuszy traktatu, począwszy od Włoch - sygnatariusza traktatów laterańskich, po państwowo laicką Francję.

Wybór formuły - deklaracji - jak i jej treść, są powszechnie odczytywane jako oznaczające niezaangażowanie religijne Unii, jej wyznaniową neutralnośćc6. Jednak z prawnego punktu widzenia, deklaracja nie ma formalnego znaczenia. Nie jest częścią prawa wspólnotowego. Składają ją poszczególne państwa, a nie Wspólnota czy Unia jako samodzielne podmioty. Nie wiąże wprost, a jedynie jest tzw. aktem około traktatowym. Zgodnie z konwencją wiedeńską o prawie traktatów z 23 maja 1969 r. dokument taki może być jednym z elementów uwzględnianych przy interpretacji umów międzynarodowych. Nie ma też styku z prawem wtórnym.

\section{TOŻSAMOŚĆ EUROPEJSKA}

\section{Treść tożsamości europejskiej}

\subsection{Istota i konotacje traktatowe}

Z omówionych wyżej norm traktatowych wynika, że tożsamość narodowa - aczkolwiek zredefiniowana na własne potrzeby - to jednak nie została $\mathrm{w}$ procesie integracji zastąpiona tożsamością ponadnarodową (europejską) zdefiniowaną na jej wzór. Jednak od zmian traktatowych w Amsterdamie, tożsamość narodowa nie jest już w prawie UE instytucja autonomiczną. Doktryna zgodnie uznaje, że właś-

${ }^{64}$ Por. Europa i Kościót, pod red. H. JurosA, cit. 
nie wtedy stworzony został system norm konstruujący tzw. tożsamość europejską.

Instytucja ta jest specyficznym tworem. Nie jest znana naukom o społeczeństwie. Jest więc konstrukcją traktatową, przyjętą wyłącznie na potrzeby procesu integracji europejskiej. Definiując tożsamość europejską należy więc sięgnąć wyłącznie do norm traktatów. Na początek należy wyjaśnić rozumienie słowa europejskość. Z nim spotykamy się w traktatach wielokrotnie. Jednak najbardziej istotne jest umieszczenie tego pojęcia jako kryterium przystapienia do UE. Zarówno $\mathrm{w}$ art. 49 TUE (każde państwo europejskie), jak i w samej nazwie traktatu oraz w preambule (,ściślejszy związek między narodami Europy”) zwrot zachęca do najprostszego skojarzenia - definiowania go w rozumieniu geograficznym. Jednak dla UE pojęcie to nie wiąże się wyłącznie z geografią. W przeciagu wielu lat integracji oraz rozciagnięcia tego procesu na poziom polityczny, europejskość nabrała także treści o charakterze aksjologicznym, stanowiąc fundament dla całego pojęcia tożsamości europejskiej.

Ze szczegółową definicją pojęcia ,europejskości” nie spotykamy się jednak w TUE ani w TWE bezpośrednio. Ale istnieje w nich szereg sugestii, które w doktrynie są przekuwane wprost w to sformułowanie $^{65}$. Kluczowe sa jednak dwie. Po pierwsze, wymiar europejski stanowi punkt odniesienia dla jednego z elementów narodowej tożsamości - kultury państw członkowskich. W art. 151 ust. 1 Wspólnota jest bowiem zobowiązana nie tylko do rozwijania kultur narodowych i regionalnych, ale i do przyczyniania się do podkreślania wspólnego dziedzictwa kulturowego. Tym samym norma buduje kulturę europejską $\mathrm{i}$ to $\mathrm{w}$ postaci przekraczającej sumę kultur narodowych. Europejska polityka kulturowa polega na podkreślaniu wspólnych

${ }^{65}$ Wynikiem tych rozważań doktrynalnych jest koncepcja spójności kulturowej powstałej przez trwałe kształtowanie tożsamości narodowych w jedną zintegrowaną wspólnotę europejską, która definiuje się nie tylko przez cele traktatowe o charakterze ekonomicznego dobrobytu i technologicznego rozwoju, ale i jako obszar kulturowej produktywności i kreatywnej innowacji”. Por. W. MaIlhofer, Zur Notwendigkeit einer europäischen Kulturföderation, [w:] H. WeIdenfeld, J. LüBBE, W. Mailhofer, H. Rovan, Europäische Kultur: das Zukunftsgut des Kontinents, Berlin 1990, s. 93. 
korzeni europejskich narodów, przez co wzmacnia spójność kulturową i wyciaga z niej tożsamość ,europejską"66 jako mieszankę religii chrześcijańskiej, greckiej filozofii i prawa rzymskiego. Z niej bowiem powstały zasady konstytucji europejskich, demokracji, państwa prawa czy sprawiedliwości społecznej, jak i prawa człowieka ${ }^{67}$. Dlatego Wspólnota uznaje się za zobowiązaną do jej ochrony, czego wyrazem jest art. 151 ust. 2 tiret $2^{68}$. Konstrukcja ta znajduje też odbicie w art. 6 ust. 2 TUE poprzez formułę, ,tradycji konstytucyjnych wspólnych dla państw członkowskich".

Drugim kluczowym miejscem kreującym europejskość jest interesujący art. 6 ust. 1 TUE. Czytamy w nim, że Unia opiera się na zasadach wolności, demokracji, poszanowania praw człowieka i podstawowych wolności oraz państwa prawnego, które są wspólne dla Państw Członkowskich.

Norma ta tworzy pewne zasady quasi konstytucyjne, których pierwotnym celem jest urzeczywistnienie spoistości między konstytucjami państw członkowskich, a unormowaniami europejskimi. Ponieważ konstytucje państwowe roszczą sobie prawo do samodzielności (powstania i funkcjonowania), dlatego reguły europejskie określają wspólnie materialne oczekiwania ${ }^{69}$. Są to: wolność i demokracja, poszanowanie praw człowieka i podstawowych wolności oraz zasada państwa prawa (praworządności). Wzmianka w normie o państwach członkowskich ma za zadanie stworzenie równowagi - nie tylko UE, ale i państwa są zobowiązane przestrzegać tych zasad. Nie jest możli-

${ }^{66}$ Porównaj: W. Mallhofer, op. cit., s. 69.

${ }^{67}$ Dokument über Europäische Identität. Europäischer Rat vom 14.12.1973 in Kopenhagen. MSZ RFN - Europäische Politische Zusammenarbeit, 1984, s. 50. Por. też: J. SchWARzE, Verfassungsrecht und Verfassungsgerichtbarkeit im Zeichen Europas, Köln 1998. s. 11 i n.

${ }^{68}$ Działanie Wspólnoty zmierza do zachęcania do współpracy między Państwami Członkowskimi oraz, jeśli to niezbędne, do wspierania i uzupełniania ich działań w następujących dziedzinach: ... zachowania i ochrony dziedzictwa kulturowego o znaczeniu europejskim ...

${ }^{69}$ A. Bogdany, Supranationaler Föderalismus als Wirklichkeit und Idee einer neuen Herrschaftsform, Berlin 1999, s. 14. 
we uchylenie się od nich np. przez zmianę konstytucji. W ten sposób przesłanki te stanowią pewien element wspólny, określany przez doktrynę pod nazwą ,tożsamości europejskiej”. To właśnie europejskość w tym kontekście jest używana przez szereg norm traktatowych, w tym art. 49 TUE.

\subsection{Kryteria tożsamości europejskiej}

a. wolność i demokracja

Pojęcie wolności jest często w doktrynie i publicystyce określane dość swobodnie jako wyznanie wartości rewolucji francuskiej. Z kolei wcześniej wolność była postrzegana w rozumieniu wytycznej politycznej dla zjednoczonej Europy, jako takiej ukierunkowanej przecież na gospodarkę. Dla prawa UE normatywne znaczenie pojęcie wolności otrzymało dopiero poprzez różnorodną konkretyzację w TWE oraz TUE, w szczególności przez przywiązanie UE do praw podstawowych w art. 6 ust. 2 TUE.

Pojęcie demokracji wiąże się natomiast z legitymacją demokratyczną, której UE jako organizacja tworząca jednolity porządek prawny i władczy zdecydowanie potrzebuje. Doktryna uznaje, że legitymacja demokratyczna pochodzi bezpośrednio z państw członkowskich, gdzie demokratycznie wybrani członkowie parlamentów zatwierdzają prawo pierwotne, demokratycznie legitymowani członkowie rządu zasiadają w Radzie, jaki i zarządzają UE nominowani przez państwa członkowie Komisji ${ }^{70}$. Taka formuła powoduje jednak, że w dyskursie publicznym często słyszymy o deficycie demokratycznej legitymacji w UE, mimo że w pewnym stopniu potwierdza ją bezpośrednio wybierany Parlament Europejski, co pozwala niektórym przedstawicielom doktryny pisać nawet o podwójnej legitymacji ${ }^{71}$. Wspiera ja również udział parlamentów narodowych w tworzeniu prawa wspólnotowego.

${ }^{70}$ V. EPPING, Die demokratische Legitimation der dritten Gewalt der Europäischen Gemeinschaften, «Der Staat» 36 (1997), s. 349.

${ }^{71}$ V. EPPING, op. cit. 
b. poszanowanie praw człowieka i podstawowych wolności

Wskazanie na prawa człowieka i podstawowe wolności odnosi się do europejskiej Konwencji o ochronie praw człowieka i podstawowych wolności, przyjętej przez Radę Europy, która zgodnie z art. 6 ust. 2 TUE jest jednym $z$ dwóch źródeł praw podstawowych. Jeśli państwo jest stroną tej Konwencji, uznaje się że spełnia tę przesłankę.

Przyjęcie Karty Praw Podstawowych, mimo pozostania na politycznym poziomie związania się nią przez państwa, tworzy drugi fundament $\mathrm{w}$ tym zakresie.

\section{c. praworządność}

ETS określa Wspólnotę Europejska jako wspólnotę prawa, nie używa jednak pojęcia praworządności ${ }^{72}$. Bez powołania się na tę regułę rozwinął on jednak trzy ogólne zasady, które z niej się wywodzą. Są to: istnienie katalogu praw podstawowych, zasada proporcjonalności oraz zasada zaufania do wspólnoty i bezpieczeństwa prawnego. Ich istnienie jest minimalnym warunkiem praworządności.

Za najważniejszą z tej triady uznaje się istnienie katalogu praw podstawowych. Jest on bowiem gwarancją przestrzegania praw, które ograniczają, wiążą i łagodzą wykonywanie władztwa wspólnotowego. Natomiast dla jednostki tworzą praktycznie nieograniczony obszar wolności. Z kolei zasada proporcjonalności jest wyrazem praworządności. Wynika $\mathrm{z}$ istoty praw podstawowych, które mogą być ograniczone tylko o tyle, o ile jest to konieczne do ochrony interesu publicznego ${ }^{73}$. Proporcjonalność opiera się na trzech elementach. Są to: konieczność, odpowiedniość i proporcjonalność środka. Oznacza, że te środki ograniczające są właściwe, które są konieczne i w danej sytuacji są najmniej obciążające.

${ }^{72}$ ETS 294/83, Opinia 1/1991 I-6079.

${ }^{73}$ ETS 265/87. 
W orzecznictwie duże znaczenie ma zaufanie do Wspólnoty ${ }^{74}$. Wiąże się z wpływem instytucji wspólnoty na pozycje prawne jednostek. Zasada ta skonstruowana jest na uznaniu interesu jednostki w istnieniu ram prawnych, na których może się ona opierać, a z drugiej strony na konieczności utrzymania politycznej giętkości i mobilności działających organów ${ }^{75}$. Wiąże się też z trzema warunkami: istnieniem obszaru zaufania, stworzeniem systemu ochrony tego zaufania i przewagi interesu jednostki nad interesem Wspólnoty. Pierwszy z nich polega na obowiązku Wspólnoty tworzenia sytuacji, które budziłyby w jednostkach zaufanie. Do tego dochodzi konieczność budowy systemu jego ochrony ${ }^{76}$. Z kolei przewaga interesu jednostki nad interesem Wspólnoty jest konsekwencją dwóch poprzednich.

Tak samo jak zasada zaufania, również zasada bezpieczeństwa prawnego wymaga stałości i nienaruszalności praw. Relacja między oboma zasadami jest w prawie wspólnotowym nie do końca wyjaśnio$\mathrm{na}^{77}$. ETS postrzega zasadę bezpieczeństwa prawnego zasadniczo jako fundament innej zasady - zakazu działania prawa wstecz. Wywodzi to $\mathrm{z}$ art. 7 europejskiej Konwencji o ochronie praw człowieka i podstawowych wolności.

\section{Instrumenty ochrony tożsamości europejskiej}

Stworzona przez Traktat o UE tzw. „tożsamość europejska” ma zadanie polityczne - stworzenie wspólnoty państw i narodów, które wyznają wartości w niej określone. $Z$ tego powodu została ona wsparta katalogiem instrumentów, których zadaniem jest zagwarantowanie jej skuteczności. Ochrona ta przybiera różne formuły (od prewencyjnej

${ }^{74}$ K. D. Borchard, Der Grundsatz des Vertrauensschutzes im europäischen Gemeinschaftsrecht, Kehl a/Rein 1988, s. 188.

${ }^{75}$ Tamże.

${ }^{76}$ Tu ETS jest bardzo zdecydowany (ETS C 258/90, ETS C 259/90; ETS C64/95, por. też K. D. BORCHARD, op. cit.).

77 Por. C-143/88; C 92/89. 
po represyjną) i ma miejsce na różnych etapach członkostwa, a właściwie pierwsza weryfikacja odbywa się już w fazie akcesyjnej ${ }^{78}$.

\subsection{Metoda prewencyjna - poszanowanie europejskich wartości przez kandydata do członkostwa}

Znacząca rola omawianych wartości wynika z faktu, że znajdują one zastosowanie już w momencie ubiegania się o członkostwo UE przez państwo spoza Unii. Do nich odsyła bowiem art. 49 TUE, który statuuje warunki przystąpienia do Unii. Zgodnie z nim o członkostwo w UE może się ubiegać tylko takie państwo europejskie, które szanuje zasady określone w artykule 6 ustęp $1^{79}$. Stają się więc one furtką do klubu krajów zintegrowanych.

Jest to ochrona prewencyjna, ponieważ nie jest możliwe zastosowanie innej procedury przyjęcia. System prawa UE stanowi self-contained regime i nie jest możliwe improwizowanie w myśl powszechnego prawa międzynarodowego. ETS uznaje to bowiem za wykluczone ${ }^{80}$. Zresztą w procedurze określoną role przypisano organom UE i nie jest możliwe pozbawienie ich tego.

Samo postępowanie ma dwie fazy, w których ocenie podlega przestrzeganie tych wartości. Pierwsza, ukierunkowana na zawarcie traktatu akcesyjnego, zaczyna się wnioskiem państwa przejawiającego chęć

${ }^{78}$ Artykuł nie zajmuje się sprawą ochrony tożsamości europejskiej w kontekście stosunków z państwami trzecimi. Dlatego pominięte są w nim rozważania nt. art. 11 TUE (zachowanie tożsamości europejskiej w ramach działań podejmowanych w ramach Wspólnej Polityki Zagranicznej i Bezpieczeństwa) oraz art. 177 ust. 2 TWE (promowanie tożsamości europejskiej w ramach współpracy w rozwoju), czy specjalnych klauzul włączanych do umów z państwami trzecimi i organizacjami międzynarodowymi.

${ }^{79}$ Art. 49 TUE, por. S. Hambura, M. Muszyński, Traktat z wprowadzeniem, BielskoBiała 2005. Norma ta zastapiła stare art. 237 TEWG, 205 TEWA, 98 TEWWS. Na jego podstawie - jeszcze jako art. O traktatu z Maastricht, do UE przystąpiły pierwsze kraje - Finlandia, Szwecja, Austria. Por. E. Klein, Zur Abgrenzung des Art. 235 EGV von der Vertragsänderung, «EuZW» (1997), s. 13. Norma reguluje też procedurę przyjęcia.

${ }^{80}$ Por. ETS 43/75 (Defrenne/Sabena); ETS 68/86 (UK/Rada). 
akcesji $^{81}$. Po zajęciu tymczasowego stanowiska przez Komisję ${ }^{82}$ (nie przewidziane w art. 49 TUE), Rada podejmuje decyzję o rozpoczęciu negocjacji akcesyjnych ${ }^{83}$. Prowadzi się je na konferencji ministrów pod przewodnictwem kierującego Radą. Przedstawiciele Komisji uczestniczą w tym procesie ${ }^{84}$. Po tym zaczyna się druga faza - proceduralna. Odbywa się ona dwutorowo - na płaszczyźnie unijnej oraz międzypaństwowej. Najpierw Rada podejmuje decyzję jednomyślnie o przyjęciu, po wysłuchaniu Komisji i uzyskaniu zgody $\mathrm{PE}^{85}$. To jest konieczne, ale jeszcze nie wystarczające do przystapienia. W drugim obszarze powstaje konieczność zawarcia miedzy państwami UE a państwem akcesyjnym umowy międzynarodowej (traktat akcesyjny). Wspólnoty nie uczestniczą w procedurze zawierania umowy ${ }^{86}$. Wynikiem jest przystąpienie do obu traktatów stanowiących fundament UE.

Sama norma tworzy też materialne warunki przystąpienia. Pozwala tylko na przyjęcie państwa. Nie jest możliwe również częściowe członkostwo (np. tylko WPZB) ${ }^{87}$. Przystapić mogą tylko państwa europejskie, przy czym nie chodzi tu wyłącznie o kryterium geograficzne, ale właśnie o kryteria kulturowe i polityczne. Mianowicie kraj uznaje się za europejski, kiedy prócz elementu geograficznego spełnia on dodatkowe kryterium - przestrzega zasad z art. 6 ust. 1 TUE. Ocena,

${ }^{81}$ K. Hasselbach, Maastricht II: Ergebnisse der Regierungskonferenz zur Reform $\operatorname{der} E U$, «BayVBl.» (1997), s. 454

${ }^{82}$ T. Wiedmann, Der Vertrag von Nizza - Genesis einer Reform, «EuR» (2001), s. 186.

${ }^{83}$ C. Vedder, H.-P. Folz, [w:[ W. Grabnitz, G. Hilf, EU/EG Kommentar, nota 26 do art. 48 EUV.

${ }^{84}$ C.O. Lenz, EGV mit Kommentar, Köln-Basel-Genf-München-Wien 1999, komentarz do art. 236, nota 5 .

${ }^{85}$ E. KLeIN, op. cit.

${ }^{86}$ Choć z drugiej strony członkostwo w UE skutkuje członkostwem we Wspólnotach. Por. L.-J. Constantinesco, Das Recht der Europäischen Gemeinschaften, BadenBaden 1977, s. 192.

${ }^{87}$ U. EverLing, Reflexion on the Structure of the European Union, «CMLRev.» 29 (1992), s. 1053. 
czy państwo „kwalifikuje się”, a więc czy posiada tzw. europejską tożsamość, jest w tym przypadku kwestią negocjacji ${ }^{88}$.

\subsection{Metoda represyjna - ochrona przez pozbawienie niektórych praw traktatowych}

Ochronę te statuuje art. 7 Traktatu o UE. Został on włączony do jego treści w trakcie nowelizacji w Amsterdamie (1997). Służy wzmocnieniu skuteczności zasad wymienionych w art. 6 ust. 1 TUE. Zasady te są skierowanym wobec państw oczekiwaniem pewnej homogeniczności ${ }^{89}$. Stanowią pewne wspólne minimum, które powinny przestrzegać kraje także po uzyskaniu członkostwa w UE.

Norma ta została znowelizowana w Nicei $(2001)^{90}$. Nowelizacja była reakcją na zdarzenia, z jakimi UE wcześniej się nie liczyła. Chodzi mianowicie o sprawę Austrii i sankcji czternastu państw członkowskich przeciwko Wiedniowi na przyjęcie do rządu FPÖ ${ }^{91}$. W stanie prawnym określonym w traktacie amsterdamskim możliwe były jedynie dwie grupy sankcji: określone w postępowaniu przed ETS za naruszenie traktatu ${ }^{92}$ oraz sankcje w przypadku naruszenia zasad wskazanych w art. 6 ust. 1 TUE zastosowane przy odwołaniu się do art. 60 ust. 2 i ust. 3 lit b. Konwencji wiedeńskiej o prawie traktatów. Po Nicei art. 7 TUE stworzył system norm sanacyjnych wiążący TUE z innymi nor-

${ }^{88}$ Zalecenia Komisji w Agenda 2000, «Bull. EG Beilage» 5 (1997). Państwo musi też być w stanie gospodarczo przyjąć acqui communitare.

${ }^{89}$ Powołanie się na art. 6 TUE jakie ma miejsce w art. 49 TUE oznacza, ze jest to warunek przystąpienia. Było to skierowane szczególnie wobec tzn. młodych demokracji w związku z planowanym rozszerzeniem UE na Wschód, ze względu na zarzut - nietrwałej konstytucyjnej stabilności. Por. K. Thun-Hohenstein, Der Vertrag von Amsterdam, Wien, 1997.

${ }^{90} \mathrm{~W}$. Hummer, W. OBweXer, Die Wahrung der Verfassungsgrundsatze der EU, «EuZW» (2000), s. 485.

${ }^{91}$ L. Adamovitsch, Juristische Aspekte der Sanktionen der EU-14 und des Weisenberichts, «EuGRZ» (2001), s. 89.

${ }^{92}$ Zgodnie $\mathrm{z}$ art. 46 TUE, ETS nie posiada kompetencji w zakresie art. 6 TUE za wyjątkiem jego ust. 2. 
mami zawartymi w traktatach wspólnotowych (art. 309 TWE, art. 204 TEWEA). Do uruchomienia się system potrzebuje decyzji w trybie art. 7 TUE. Jeśli zostanie podjęta, skutek jej przechodzi w obszar wspólnotowy automatycznie.

Norma zawiera trzystopniowy mechanizm. Pierwszy poziom - tzw. system wczesnego ostrzegania, dotyczy zagrożenia naruszenia zasad $\mathrm{z}$ art. 6 TUE. Rada może stwierdzić ,,istnienie wyraźnego ryzyka poważnego naruszenia zasad". Norma upoważnia też do zamówienia zewnętrznego sprawozdania (tzw. raportu mędrców) w tej kwestii i przyjęcia zaleceń dla państwa, którego to dotyczy. Poziom drugi - odnosi się do możliwości stwierdzenia zaistnienia ,poważnego i stałego” naruszenia. Jest to wynik decyzji Rady przyjęty w określonej procedurze. To otwiera drogę do trzeciego etapu - podjęcia przez Radę decyzji w postaci sankcji dla państwa naruszającego (ust. 3). Na tym etapie istnieje pole decyzyjne odnośnie rodzaju i zakresu sankcji. Rada jest jednak ograniczona prawami jednostek.

Zgodnie z wykładnią literalną traktatu, nie musi dojść do naruszenia wszystkich zasad z art. 6 TUE ${ }^{93}$. Wystarczy, że naruszana jest tylko jedna $z$ nich. Mamy z tym do czynienia kiedy prawne gwarancje tych zasad są formalnie zniesione lub zawieszone. Może do tego dojść również w sposób faktyczny, przez działanie organów państwowych. Usprawiedliwienie takiej sytuacji nie jest możliwe. Samo naruszenie musi być poważne i stałe. Obie przesłanki powinny pozostać w koniunkcji. Przesłanka stałości oznacza, ze zwykłe czasowe naruszenie nie może stanowić podstawy do działania. Ocena stałości jest indywidualna dla każdej z zasad z art. 6 ust. 1 Traktatu o UE ${ }^{94}$.

Etapy procedowania są następujące: procedura rozpoczyna się ze stwierdzeniem wyraźnego ryzyka poważnego naruszenia. Ma on za zadanie prewencyjne działanie zapobiegające samemu naruszeniu. Pod pojęciem ryzyka jest rozumiana sytuacja, kiedy w przypadku działania bez jakiejkolwiek przeszkody pojawia się prawdopodobieństwo graniczące $\mathrm{z}$ pewnością, że naruszenie zasad z art. 6 TUE na-

${ }_{93}$ Por. art. 6 TUE.

${ }^{94}$ F. Schorkopf, Hegemonitat in der EU, Berlin 2000, s. 149 
stapi. Przesłanka „wyraźne” podkreśla znaczne prawdopodobieństwo. Dotyczy to oceny, jak i prognozy tego co się wydarzy, choć jak pokazał właśnie przypadek Austrii, trudno poważnie brać słowa polityków w kampaniach wyborczych ${ }^{95}$. Rada może skierować też zalecenia, jak rozładować zagrożenie. Nie jest jednak ono wiążące prawnie. Politycznie zakłada się jednak, ze zachowanie państwa w sprawie zalecenia powinno być podstawą do ewentualnej oceny na kolejnym stopniu procedowania.

Norma wskazuje też podmioty upoważnione do wszczęcia procedury: 1/3 państw członkowskich, Parlament Europejski lub Komisję. Ich wystąpienie zobowiązuje Radę do działania. Przed tym wysłuchuje ona podejrzane państwo, które przedstawia własną ocenę sytuacji, a wysłuchuje oceny organów unijnych. Ma też możliwość zareagowania i rozładowania sytuacji. Rada może również powołać niezależne osoby, i zlecić im przygotowanie oceny sytuacji w postaci sprawozdania w określonym terminie. To musi nastapić przed decyzją o stwierdzeniu naruszenia. Za niezależnych uznaje się te osoby, które nie pozostają w związku zawodowym z organami UE i państwami członkowskimi. Nie mogą oni wcześniejszymi opiniami publicznymi sprawiać wrażenia zależności lub posiadania już oceny przed zbadaniem sprawy. Rada daje konkretne zlecenie określające przedmiot i zakres badania.

Po wysłuchaniu państwa i ewentualnym sporządzeniu tzw. „raportu mędrców", Rada może stwierdzić istnienie wyraźnego zagrożenia ciężkiego naruszenia $\mathrm{w}$ procedurze określonej w normie (4/5 państw za zgodą PE - ust. 5 i ust. 6). Nie jest wyraźnie żądane uzasadnienie. Jednak zaleca się je ze względów praworządności.

Przez cały czas procedowania Rada jest zobowiązana do obserwacji, czy zagrożenie trwa. Dlatego musi oceniać sytuację w danym kraju. Jeśli zaobserwuje zmianę, może albo odstapić od procedowania (jeśli zagrożenie mija) albo przejść na kolejny etap.

${ }^{95}$ Por. Raport Mędrców - ocena FPO, «EuZGR» (2000), s. 404. 
Tylko Rada może stwierdzić zaistnienie naruszenia ${ }^{96}$. Należy to do jej obszaru decyzyjnego ${ }^{97}$. Stwierdzenie jest warunkiem dla podjęcia sankcji wg ust. 3. Stwierdzenie jest wiążące dla wszystkich organów UE i państw członkowskich. Wiąże się ze specjalnymi normami sanacyjnymi z art. 309 Traktatu ustanawiającego WE, czy art. 204 Traktatu ustanawiającego Europejską Wspólnotę Atomową. Ponadto obowiązuje ono w sferze azylowej, ponieważ taki kraj nie może być postrzegany jako tzw. „bezpieczne państwo" przez te stosowne organy ${ }^{98}$.

Norma pozwala na pozbawienie takiego państwa określonych praw z zakresu Traktatu o UE włącznie z prawem głosu. Doktryna często zadaje pytanie, czy dotyczy to także II i III filara, ponieważ oznaczałoby działanie innych państw na terytorium danego bez jego zgody ${ }^{99}$ Wykładnia literalna normy daje tu odpowiedź przeczącą. Zakres pozbawienia praw należy do kompetencji Rady. Ramy dla sankcji stanowią prawa i obowiązki jednostek. Traktatowe obowiązki państwa obłożonego sankcją pozostają wiążące.

Jeśli państwo uznaje decyzje Rady lub nałożenie sankcji za bezpodstawne, art. 46 lit e Traktatu o UE daje mu możliwość ochrony przed

${ }^{96}$ Postępowanie przebiega w następujący sposób. Rada zebrana w składzie szefów państw lub rządów, stanowiąc jednomyślnie na wniosek jednej trzeciej Państw Członkowskich lub Komisji i po uzyskaniu zgody Parlamentu Europejskiego, może stwierdzić, po wezwaniu rządu Państwa Członkowskiego do przedstawienia swoich uwag, poważne i stałe naruszenie przez to Państwo Członkowskie zasad określonych w artykule 6 ustęp 1 traktatu o UE. Po dokonaniu stwierdzenia na mocy ustępu 2, Rada, stanowiąc większością kwalifikowaną, może zdecydować o zawieszeniu niektórych praw wynikających ze stosowania niniejszego Traktatu dla tego Państwa Członkowskiego, łącznie z prawem do głosowania przedstawiciela rządu tego Państwa Członkowskiego w Radzie. Rada uwzględnia przy tym możliwe skutki takiego zawieszenia dla praw i obowiązków osób fizycznych i prawnych. Rada może następnie, stanowiąc większością kwalifikowaną, zdecydować o zmianie lub uchyleniu środków podjętych na podstawie ustępu 3, w przypadku zmiany sytuacji, która doprowadziła do ich ustanowienia.

${ }^{97}$ F. SchORKOPF, op. cit., s. 158

${ }^{98}$ Por. Protokół w sprawie azylu dla obywateli państw członkowskich C. 340/103

${ }^{99}$ M. Pechstein, CH. KönIG, Europaische Union, Tubingen 1998, nota 466 
ETS w zakresie proceduralnym. Istnieje też możliwość kontroli sankcji w trybie 230 Traktatu ustanawiającego $\mathrm{WE}^{100}$.

\subsection{Metoda negatywna - zakaz dyskryminacji ze względu na narodowość}

Zakaz wprowadza art. 13 TWE. Czytamy w nim, że Rada może podjąć środki niezbędne w celu zwalczania wszelkiej dyskryminacji m. in. ze względu na pochodzenie etniczne.

Norma ta została włączona do Traktatu ustanawiającego WE przez traktat amsterdamski ${ }^{101}$. Uzupełnia znajdujący się tam art. 12 (zakaz dyskryminacji z powodu obywatelstwa) tak dalece, że blokuje możliwość dyskryminacje ze wszystkich możliwych przyczyn. Nie oznacza jednak wprowadzenia ogólnej zasady równości czy przynajmniej bezpośredniego bieżącego zakazu nierównego traktowania $\mathrm{z}$ wymienionych powodów. Jej zakres treściowy pozostaje z tyłu za art. 12 TWE, ponieważ nie jest skuteczna bezpośrednio, a ma jedynie charakter kompetencyjny. Nie mogą powoływać się na nią jednostki ${ }^{102}$, dlatego nie była krokiem w kierunku tworzenia katalogu praw podstawowych ${ }^{103}$.

Norma przypisuje Radzie kompetencje w sprawach dyskryminacji z różnych powodów. Chodzi zatem o stworzenie podstawy prawnej, z której skorzystać może tylko Rada - nie naruszając innych przepisów i jedynie jeśli inne normy nie dają podstawy do stosownych działań antydyskryminacyjnych ${ }^{104}$. Rada może działać tylko w ramach kom-

${ }^{100}$ W. Hummer, W. ObweXer, op. cit., 190.

${ }^{101}$ Szerzej por. M. Bell, The New Article 13: A Sound Basis for European AntiDiscrimination Law? «MJ» (1999) s. 5.

102 M. Rossi, Das Diskriminierungsverbot nach art. 12 EVG, «EuR» (2000), s. 197.

${ }^{103}$ Argument, że zawiera stosowny zakaz dyskryminacji nie daje się utrzymać co najmniej z dwóch powodów: po pierwsze, przepisy wydane na podstawie tej normy musza mieć zawsze określony wyraźny zakres stosowania, po drugie - musza być pokonane przeszkody proceduralne wpisane w naturę przepisu, w szczególności w ust. 1 zasada jednomyślności. Por. R. Holoubek, [w:] G. Schwartze, EU-Kommentar, komentarz do art. 13 nota 9.

${ }^{104}$ Co innego obowiązuje natomiast w relacjach między art. 13 TWE a art. 308 
petencji przekazanych przez państwa członkowskie Wspólnocie ${ }^{105}$. Może więc działać na rzecz usunięcia dyskryminacji tylko w zakresie wspólnotowych kompetencji powierzonych. Przy tym może jedynie powoływać się na materialny zakres kompetencji, a nie na dopuszczalna formułę działania. Stąd utrzymuje się, że art. 13 nie przypisuje Wspólnocie żadnej generalnej kompetencji do zwalczania dyskryminacji, a ma tylko uzupełniający charakter.

W kwestii rodzaju środka, Rada ma duże pole swobody. Może podjąć każde uzgodnione działanie w celu zwalczania dyskryminacji. Może sięgnąć po każdy środek udostępniony jej przez traktat, działając jednak zgodnie z zasadą subsydiarności ${ }^{106}$.

Z uwagi na aspekt materialny, środki muszą odnosić się do stanów faktycznych z zakresu przepisu. Rada nie może wiec na tej podstawie urzeczywistniać ogólnych zasad rozumianej przez nią równości. Właściwie pojęcie dyskryminacji musi mieć - w nawiązaniu do art. 12 TWE - nie tylko formalne, ale i materialne znaczenie. Musi więc dojść nie tylko do formalnej dyskryminacji - co ma coraz rzadziej miejsce - ale i dyskryminacji faktycznej ${ }^{107}$. To uwzględnia warunki, że mimo efektywnej gwarancji równości prawnej, równość szans różnych osób - w dużej mierze na podstawie faktycznych warunków

TWE. Ponieważ ta ostatnia norma jest subsydiarną podstawą prawna, art. 13 idzie przed nią. Mimo że sam art. 13 ma taką samą subsydiarną naturę. Przeciwko temu poglądowi nie można też zarzucić sprzeczności z deklaracją 22 do aktu końcowego traktatu amsterdamskiego. Wywodzi ona bowiem że środki na podstawie art. 95 TWE muszą uwzględniać potrzeby osób niepełnosprawnych; raczej ta deklaracja potwierdza tę tezę. W zakresie, w którym obok innych podstaw kompetencyjnych, również art. 95 ust. 1 TWE wchodzi w grę, normalny jest powołanie się na art. 3 TWE. Tym samym przepis ten pozwala nawet w pierwszym rzędzie na wydawanie specyficznych i skierowanych na zwalczanie dyskryminacji norm. Praktycznie art. 13 TWE nie może znaczyć, można ograniczać zakres materialny innych norm, a w ten sposób, by nie obejmowały spraw dyskryminacji.

${ }^{105}$ G. Jochum, Der neue Art. 13 EGV oder ,political correctness" auf Europäisch? «ZRP» (1999), s. 279.

${ }^{106}$ Art. 5 ust. 2.

${ }^{107}$ Por. G. Jochum, op. cit., s. 279. 
różnorodnej natury (struktura społeczna, określone zachowania, stereotypowe role płci, różne warunki gospodarcze, itp.) - nie zawsze jest zagwarantowana.

Dość skomplikowana jest też procedura decyzyjna. Rada podejmuje decyzje jednogłośnie, po wysłuchaniu Parlamentu Europejskiego. Wynika to z faktu, że kompetencji przypisanych Wspólnocie w tej normie nie można postrzegać jako jej głównego uprawnienia. Chodzi jedynie o zagwarantowanie równowagi. W traktacie z Nicei zasada jednomyślności została nieco zrelatywizowana. Wspólnotowe środki zachęcające, z wyłączeniem harmonizacji przepisów ustawowych i wykonawczych, poddane są procedurze współtworzenia.

Norma ze względu na swój charakter nie jest podstawą dla licznych aktów wspólnotowych prawa wtórnego. W interesującym nas zakresie wydana jednak została dyrektywa nr 2004/43 w sprawie stosowania zasad równego traktowania bez zróżnicowania z powodu rasy czy pochodzenia etnicznego ${ }^{108}$. Jej celem jest zakazanie kompleksowo bezpośredniej lub pośredniej dyskryminacji z powodu rasy lub pochodzenia. Zarówno w relacjach państwo-jednostka, jak i w relacjach między jednostkami. Przy czym ten ostatni przypadek jest wywiedziony w art. 3 dyrektywy. Z uwagi na zabezpieczenie wykonania tych roszczeń, państwa członkowskie mają zgodnie z jej art. 7 przewidzieć i wprowadzić odpowiednie postępowanie zabezpieczające odpowiadające wymogom art. 8 dyrektywy. Dyrektywa odwołuje się do kompetencji powierzonych Wspólnocie, ale rezygnuje z szczegółowego opisu swego zakresu przedmiotowego ${ }^{109}$.

\section{Podsumowanie}

1. Pojęcie tożsamości narodowej do chwili włączenia go do traktatu o UE nie było instytucją definiowaną przez normy prawne. Stanowiło dla nich jedynie punkt odniesienia. Było natomiast zdefiniowane w innych naukach społecznych (socjologii), a nauka prawa jedynie posłu-

${ }^{108}$ Dz.Urz. WE 2000, L. 180, 22.

${ }^{109}$ I możliwie sprzeczne z konstytucją z powodu takiego samego traktowania. 
giwała się nim. Przyjęta w 1992 r. w Maastricht konstrukcja stworzyła dla prawa UE własna definicję. Z porównania pojęcia socjologicznego i pojęcia prawnego wynika, że tożsamość narodowa w ich rozumieniu nie jest identyczna. Jako konstrukcja prawna jest ograniczona do niektórych składników definicyjnych rozumienia socjologicznego, co de facto pozwala na uznanie jej za definicję ułomna. Przenosi bowiem w obszar normatywny tylko zasadnicze elementy definicyjne instytucji istniejącej w obszarze życia społecznego i politycznego.

Jeśli przyjrzymy się historii procesu integracji, dostrzeżemy że początkowo, tożsamość narodowa (we własnym rozumieniu) była jednym z jego fundamentów. Tworzyła też element składowy konstrukcji nowej konstrukcji wprowadzonej do procesu integracji - tzw. tożsamości europejskiej. Prawdopodobnie jednak stanowiła istotne ograniczenie projektu nazwanego Unią Europejska. Dlatego dokonana w Amsterdamie zmiana art. 6 ust. 1 TUE spowodowała autonomizację instytucji ,tożsamości europejskiej” wobec tożsamości narodowej. Oparła się ona na własnych traktatowych przesłankach, które mają stanowić zespół odrębnych kryteriów łączących państwa członkowskie UE i stanowić pewne minimum, pozwalające na uznanie kraju za ,europejski". Słabym punktem tożsamości europejskiej jest natomiast jej negocjacyjny charakter. Spełnienie przesłanek jest bowiem przedmiotem rokowań politycznych, co wpływa na osłabienie jej obiektywnego oddziaływania.

Początkowo obie instytucje funkcjonowały bezkolizyjnie. Jeśli istniało zagrożenie dla tożsamości narodowych państw członkowskich, wynikało ono z naturalnej ingerencji norm wspólnotowych w takie obszary jak: kultura narodowa, historia, moralność itp. Jednak poprzez przypisane państwu narzędzia traktatowe, mogło ono osłabić lub wyeliminować ten negatywny skutek. Dziś możemy zaobserwować pierwsze przejawy zazębiania się obu konstrukcji. Wynika to z różnych przyczyn. Tożsamość europejska wprowadza do świadomości narodu jako trwałe jej elementy pewne wartości polityczne i społeczne, tj. wolność i demokrację, poszanowanie praw człowieka i podstawowych polności, praworządność. Dzieje się tak, ponieważ wartości te 
funkcjonują jako kryteria przystapienia do UE. Musza więc być częścią państwowej, a więc i narodowej świadomości.

Wiąże się to również $\mathrm{z}$ faktem, że poszczególne kryteria instytucji tożsamości europejskiej stają się przedmiotem procesu doprecyzowania i rozwoju, w szczególności na etapie akcesji do UE. W ten sposób w zindywidualizowanych obszarach tematycznych może dojść do zderzenia ich z elementami definicyjnymi tożsamości narodowej, postrzeganej z perspektywy prawa UE jaki i socjologii. Klasycznym przykładem może być tu ewolucja katalogu praw człowieka i jego formalizacja w prawie UE w postaci Karty Praw Podstawowych. Niektóre normy tego aktu - dotyczące np. kwestii obyczajowych - mogą wpłynąc na ewolucję obyczajów i moralności publicznej narodów państw członkowskich. Niektóre z nich mogą też wzmacniać narodowe tożsamości. Dlatego użyty wyżej zwrot ,zazębianie się” należy postrzegać nie tylko jako naturalne tarcie, ale i możliwość wzmacniania.

2. Wiele się mówi w Polsce o zachowaniu tożsamości narodowej, polskiej kulturze, czy narodowych wartościach. Ciagle przy tym pokutuje w tej kwestii opinia, że kształt prawa wspólnotowego zapewnia ochronę tych wartości poprzez pozostawienie państwom członkowskim kompetencji w tym obszarze. W rzeczywistości rola państwa nie jest tu wcale taka oczywista. Kształt przyjętych norm zdecydowanie ją osłabia, a eksponowanie jego roli może się odbywać wyłącznie przez interpretację a contrario.

Wiąże się to $\mathrm{z}$ faktem, że w sferze tożsamości UE daje państwom tyle kompetencji, ile jest niezbędne do zapobieżenia politycznym problemom narodowościowym. Konstrukcja norm wspólnotowych chroniących narodową tożsamość przed wpływem nadrzędnych wspólnotowych wolności jest tak zbalansowana, że w dużej mierze to od konkretnego państwa i jego polityków zależy stopień realnej ochrony. Jeśli będzie potrafiło z niego korzystać i upominać się o swe prawa, rozwiązania europejskie będą działać na korzyść narodu i państwa narodowego. W przeciwnym razie, w dłuższej perspektywie pozbawione narodowych elementów rozwiązania wspólnotowe roztopią naród w tzw. europejskości. 
3. Kompetencje państw w zakresie poszczególnych elementów tożsamości są zróżnicowane. Najszersze są w kwestii języka. Całkowicie poza obszar regulacyjny wyrzucona jest sprawa religii i obyczajów. W sferze kultury Wspólnota natomiast ingeruje w dyskrecjonalne uprawnienia państw członkowskich, poprzez próby znalezienia elementów wspólnych (europejskich) dla indywidualnych kultur państw członkowskich.

Dzieje się tak już od lat 80. XX w. Wówczas jednak Wspólnota nie mogła konkurować z polityką kulturalną państw członkowskich stanowiąca wyraz narodowej tożsamości. W 1992 r., przyznając Wspólnocie kompetencje o charakterze komplementarnym w obszarze kultury, twórcy Traktatu ustanawiającego WE dokonali jednoznacznej ingerencji w zakres kompetencji państw. Od tego czasu państwa muszą współpracować nie tylko między sobą w sprawach kultury, ale - wobec jasno określonych uprawnień wspierających WE - mają taki obowiązek wobec organów wspólnotowych, które z kolei dbają o eksponowanie wspólnego, europejskiego dziedzictwa.

Ten ponadnarodowy wymiar kształtowany jest przez obowiązek WE do „wnoszenia wkładu” w rozwój kultur narodowych. Nie odbywa się to jednak z ukierunkowaniem na ich indywidualizm, ale jedynie przy poszanowaniu ich różnorodności. Ochrona tożsamości narodowej jest więc pozostawiona samym państwom członkowskim. Cel działania wspólnotowego jest bowiem przeciwny - eksponowanie wspólnego dziedzictwa europejskiego. W ten sposób Traktat ustanawiający WE tworzy ponadnarodową kulturę europejska, rozumianą jako sumę wybranych elementów kultur narodowych. Używając języka ekonomicznego należałoby powiedzieć, że powstaje tzw. wartość dodana, stanowiąca wspólne korzenie kulturowe.

4. Interesująca, choć może pozostające z boku niniejszych rozważań, jest uwaga, że normy UE nie chronią kultury mniejszości narodowych w państwa członkowskich. Adresatem normy wspólnotowej jest bowiem kultura państw członkowskich jako całość. Kultura mniejszości narodowych, która stanowi element odrębny w kulturze ogólnonarodowej, jest swoistym obcym ciałem w kulturze państw członkowskich 
i jest pominięta w treści przepisów. Dlatego los „,kultury” mniejszości narodowej w ramach chronionej przez TWE kultury całego państwa zależeć będzie wyłącznie od prawnego statusu mniejszości narodowych w państwie członkowskim. Wiąże się z jednym $\mathrm{z}$ instrumentów - możliwością subwencjonowania przez państwo różnych przedsięwzięć związanych z kulturą, także aktywności np. organizacji mniejszości narodowych. Nie obejmuje jednak ich promowania poprzez art. 151 TWE.

To powoduje przesunięcie decyzji w płaszczyznę prawa wewnętrznego, dla którego jedyną, słabą wytyczną jest art. 13 TWE. Stworzona przez niego ogólna zasada prawa jest poprzez art. 6 ust. 2 Traktatu o UE skonkretyzowana dopiero w europejskiej Konwencji praw człowieka i podstawowych wolności. Proces odbywa się więc właściwie dopiero poza UE, w płaszczyźnie prawa międzynarodowego publicznego.

5. W UE brak jest rozwiązań statuujących kościoły jako samodzielne podmioty prawa wspólnotowego. Na dodatek w przyjętej deklaracji zrównuje się je z organizacjami niewyznaniowymi. Powoduje to deficyt prawno-instytucjonalny. Kościoły i wspólnoty są postrzegane w sposób ułomny, jedynie przez kontekst gospodarczy. Występująjako uczestnicy rynku, co nie jest ich główną rolą. Przypomnijmy też, że każdy z krajów UE indywidualnie definiuje swój stosunek do kościoła np.: Portugalia przez rozdział, Belgia przez tzw. „uznanie”, Francja przez laickość, Polska poprzez konkordat, a Włochy dopuszczają istnienie suwerennego państwa Watykan w swoich granicach terytorialnych. Prawna ignorancja Unii może spowodować efekt uboczny, który odbije się na tożsamości. Dlatego patrząc z tej perspektywy, należy ocenić deklarację jedynie jako zbyt wątły krok we właściwym kierunku.

6. Konkluzja, że prawo UE jest ukierunkowane wprost na eliminacje poczucia świadomości narodowej społeczeństw krajów UE, byłaby zbyt mocna. Szereg rozwiązań wspólnotowych stara się wręcz uwzględnić elementy tożsamości narodów Europy jako jednego z czynników łagodzących proces integracji. Trafne jest jednak sformułowanie, że prawo UE jest nastawione na promocję tożsamości europejskiej, tożsamość narodowa przyjmuje w nim rolę specyficznego zastrzeżenia traktato- 
wego. Podkreśla to konstrukcja art. 6 ust. 3 Traktatu o UE oraz specyfika instrumentów chroniących obie te konstrukcje. Potrzebna jest więc świadoma i konsekwentna aktywność państwowa, by w tej koegzystencji dwóch tożsamości chronić tożsamość narodową, jako systemowo $\mathrm{i}$ instytucjonalnie słabszą.

Standardized Awareness. National and European Identity as a Matter of the European Union LaW

\section{Summary}

Since the very beginning of the European integration process, the national identity has constituted a problematic issue for the integration as such. The main question was, whether the national identity is an opportunity or an obstacle to the European Union. The national identity constitutes collective awareness - comprising such elements as "material culture" (history, literature, arts, music, folklore), language, spiritual culture (customs, public morality, religion) and legal culture.

Initially, the European Union welcomed these distinguished characteristics. The European Union founders believed that for its durability the community needs not only an open economic area but also social diversity. Hence, the Maastricht Treaty establishing the European Union includes an article guaranteeing the national identity of the European Union member states. The obligation to respect the national identity is associated with instruments that are left to the disposal of the member states. In this respect, two groups of treaty provisions are to be distinguished.

Some of the existing treaty provisions require that the European Community operate to preserve the national identity (to stimulate, to support and to supplement the member states activities in the field of propagation of culture and history, preservation of national heritage and in non-commercial exchange of literary and art works). Other treaty provisions block Brussels' (the European Union's organs) actions against those member states which for the purpose of preserving national identity, infringe the regulations of the European Community. 
In the Amsterdam Treaty of 1997, its authors introduced a system reconstruction of the ideological foundations of the European Union. Although the national identity has not been replaced with the supranational identity, the new axiological fundament of the united Europe was defined. It should be stressed that the Amsterdam Treaty created so called "European identity" existing parallel to the national identity One of the treaty goals is to transform the national-particularistic way of thinking about the European Union citizens into the "European awareness". The European Union is obliged not only to support the State Parties' culture but also to display all of the axiological elements that are common for the entire European continent. Hence, national identity as a sociological value is no more autonomic. The European Union started to create a substrate of the European culture that has gone beyond the simple sum of national's cultures, which would be the basis for the future European statehood.

What remains unanswered is whether the European identity created in such a way poses a threat to the national ties or not. National and European identities are autonomous institutions only on the surface. European standards of human rights protection go far beyond political and economic rights. These standards interfere in customs and traditions and in public morality of nations, trying to find a balance between them. In reality, the danger of such a process is correlated with the nature of the economic integration as well. In the process of creation of the law of the European Union, economic issues are treated with priority. Hence, free trade undermines the protection of works of art, open borders create favourable conditions for the transfer of pornography as well as the trend to re-define the history. Therefore, the authors of the treaties have created a "safety valve" - all of the aforementioned norms which constitute legal instruments of protection of the national values. Hence, the problem consists in their proper use by the member states. 